\title{
UWARUNKOWANIA DUCHOWOŚCI ZGROMADZEŃ ZAKONNYCH ŻYCIA UKRYTEGO W KRÓLESTWIE POLSKIM W XIX WIEKU
}

Na przestrzeni dziejów Kościoła stwierdza się fakt istnienia różnych duchowości, który wynika m.in. z wielości form życia zakonnego. Racja bytu określonej duchowości ma swoje źródło w potrzebach religijnych, uwarunkowaniach eklezjalnych, społecznych i politycznych. Wiek XIX był stuleciem o istotnym znaczeniu dla zmian zachodzących w życiu zakonnym. Złożyły się na to rewolucje polityczne, przewroty ekonomiczne i naukowe, nowe prądy umysłowe, walki narodowo-wyzwoleńcze i ruchy społeczne. Począwszy od drugiej połowy XVIII w. problemem Kościoła stały się kasaty zakonów. Miały miejsce w wielu krajach, w odmiennych warunkach społecznopolitycznych, a ich zasięg był różny. Na ziemiach dawnej Rzeczpospolitej organizatorami kasat były przede wszystkim władze zaborcze. Zasadniczo dokonywano likwidacji klasztorów w latach 1773-1879. Lata siedemdziesiąte XIX w. były początkiem formowania się zgromadzeń zakonnych prowadzących życie ukryte. U początków tej formy życia zakonnego stoi kapucyn - o. Honorat Koźmiński. Chociaż historia Kościoła i życia zakonnego związana jest z dziejami ludzkości $\mathrm{i}$ to w różnych jej wymiarach, to jednak nie można wszystkich przeobrażeń i nowych zjawisk zachodzących we wspólnocie wierzących tłumaczyć jedynie na płaszczyźnie historycznej czy socjologicznej. Nie można także zredukować ideału życia ukrytego propagowanego przez o. Honorata wyłącznie do niehabitowości. Ten styl życia w Kościele tworzy swoistą duchowość. Podejmując problematykę uwarunkowań duchowości zgromadzeń przez niego zakładanych, należy znaleźć racje stanowiące o istocie takiej formy życia zakonnego w wymiarze historyczno-społecznym i teologiczno-eklezjalnym.

„Nasza Przeszłość” t. 131: 2019, s. 5-41. 


\section{Duchowość}

Błogosławiony kapucyn z Białej Podlaskiej, poucza, że duchem komuś właściwym (duchowością) nazywamy zwykle to, co cechuje i ożywia czynności podejmowane przez pojedynczą osobę lub wspólnotę osób. Duchowość odnosi się do określonych zasad życia, celów jakie dane osoby sobie zakładają i środków, które stosują do ich realizacji. Duchowość, która obejmuje najbardziej intymne pokłady ludzkiego wnętrza, mówi o zapatrywaniu się na rzeczy Boże i ziemskie, co najbardziej trafia do przekonania danej osoby i do czego sercem najbardziej przylega ${ }^{1}$.

Duchowość pojawia się tam gdzie żyje i działa osoba. Wyraża się w wartościach ogólnoludzkich tj. pracy, myśli, symbolu, mowie, sztuce, kulcie, religii, kulturze, nauce. Jednak ona się tylko przez te wartości wyraża i nie można jej z nimi utożsamiać ${ }^{2}$. Tym, co pozwala określone aktywności identyfikować jako przejaw duchowości, jest odniesienie osoby do Boga. Duchowość jest takim udzielaniem się życia Bożego, że osoba staje się rzeczywistym uczestnikiem natury Bożej (por. 2P 1, 4), dzieckiem Bożym (por. 1J 3, 1). Wszystko, czym jest i co czyni w stanie łaski uświęcającej, ma wartość nadprzyrodzoną, bo uczestniczy w Bożej duchowości ${ }^{3}$.

Duchowość, to pewien styl życia, życie według Ducha (por. Rz 8, 9), postępowanie według Ducha (por. Rz 8,4), to zespół postaw ludzkich serc pobudzonych przez Ducha, a więc przekonań, motywacji, decyzji. Jest to zespół postaw, mających odniesienie intelektualno-poznawcze, emocjonalno-wartościujące i behawioralne ${ }^{4}$. Duchowość jest pewnym charakterystycznym nastawieniem na specyficzne wartości, które

\footnotetext{
${ }^{1}$ Por. H. K o źm i ń s k i, Święty Franciszek Seraficki jego życie, wielkie dzieła, duch, pisma i nauki i ich odbicie w naśladowcach Jego (dalej: ŚFS), Warszawa 1913, t. 4, s. 11.

${ }^{2}$ Por. A. J. N o w a k, Duchowość osób konsekrowanych, [w:] Vita consecrata. Adhortacja. Tekst i komentarz, red. A. J. N o w a k, Lublin 1998, s. 179n; H. L a n g k a m mer, Duch Święty a duchowość, Wrocław 1999, s. 10n; M. Chmielew k i, Metodologiczne problemy posoborowej teologii duchowości katolickiej, Lublin 1999, s. $87 \mathrm{n}$.

${ }^{3}$ Por. A. Ż y n e 1, Duchowość chrześcijańska i jej podstawy w świetle teologii posoborowej, [w:] Chrześcijańska duchowość (seria „W nurcie zagadnień posoborowych”, t. 14), red. B. B e j z e, Warszawa 1981, s. 12.

${ }^{4}$ Por. W. S ł o m k a, Teologia duchowości, [w:] M. C h mi e le w s k i, W. S ł o m k a, Polscy teologowie duchowości, Lublin 1993, s. 233n.
} 
pragnie się osiągnąć, rozwijać, przeżywać i przekazywać. Osoba, czy też grupa osób, żyjąc danymi wartościami, czerpie z nich natchnienie do pracy, ćwiczeń duchowych, prowadzonych dziel ${ }^{5}$.

Specyficzna duchowość osób zakonnych rozumiana jest jako konkretny wzór relacji z Bogiem i ze środowiskiem, wyróżniający się swoistymi cechami oraz formami działalności, które ukazują i uwypuklają ten czy inny aspekt jednej tajemnicy Chrystusa. Sam Bóg, objawiając się w Jezusie Chrystusie, ukrywa siebie. Ukrycie to rozpoczyna się w akcie Wcielenia, przejawia w różnych momentach ziemskiego życia Jezusa, dopełnia na krzyżu, a dzisiaj uobecnia w tajemnicy Eucharystii. Duchowość to konkretna forma przeżywania tego misterium Christi i naśladowania Go.

Życie w Chrystusie staje się również włączeniem w Jego organizm, jakim jest Kościół. Duchowość chrześcijańska realizowana jest w Mistycznym Ciele, ponieważ Jezusowa preegzystencja trwa nadal w Kościele, w którym On sam wraz z Duchem Świętym dają zbawienie, uświęcają i prowadzą do Ojca. Chrześcijanin, żyjąc sprawami Kościoła i dla Kościoła, uświęca się w Kościele i poprzez Kościół, przyczyniając się jednocześnie do tego, aby stawał się On czytelnym znakiem Chrystusa ${ }^{6}$. Duchowość zgromadzeń zakonnych zakładanych przez bł. Honorata Koźmińskiego kształtowała się w XIX-wiecznym kontekście życia społeczno-polityczno-eklezjalnego w Królestwie Polskim. Był głęboko przekonany, że zakonne życie ukryte w Kościele jest najlepszym i najskuteczniejszym sposobem nie tylko odrodzenia życia zakonnego, ale przede wszystkim ocalenia życia religijnego: „Po skasowaniu zakonów wiele dusz, pragnących służyć Bogu, nie miało

\footnotetext{
${ }^{5}$ Por. O. F i l e k, Wokół terminu „,duchowość”, „Roczniki Teologiczno-Kanoniczne” 3(1966), s. 48n.

${ }^{6}$ Por. M. Chmi e lews ki, Metodologia duchowości katolickiej, [w:] Teologia duchowości katolickiej, s. 68; T e n ż e, Duchowość wedtug Jana Pawła II. Studium na podstawie encyklik $i$ adhortacji, Lublin 2013, s. 71; S. U r b a ń s k i, Mistyczne perspektywy rozwoju duchowego chrześcijanina wskazane przez Jana Pawła II na początku trzeciego tysiaclecia, [w:] Duchowość na progu trzeciego tysiaclecia, red. M. C h m i e 1 e w s k i, Lublin 1999, s. 108-110; H. La n g h a m m e r, Duch Święty a duchowość, s. 55; T e n ż e, Biblijne podstawy duchowości chrześcijańskiej, Wrocław 1987, s. 33-34; I. W e r b iń s k i, Jedność i wielość duchowości, [w:] Teologia duchowości katolickiej, red. W. S ł o m k a, M. C h m i e l e w s k i, J. M i s i u r e k, A. J. N o w a k, Lublin 1993,s. 77; K. S y n o w c z y k, Obecność ukryta na podstawie pism bt. Honorata Koźmińskiego, Kalwaria Zebrzydowska 2012, s. 5.
} 
gdzie się umieścić, potrzeba przeto było obmyślić sposób zaspokojenia ich pragnień, odpowiedni do okoliczności, miejsca i casu"”.

\section{Sytuacja polityczna}

Ukrycie w ujęciu Koźmińskiego jest wartością, a nie niedogodnością, formą zastępczą czy ograniczeniem; jest wyborem, a nie czymś narzuconym lub podyktowanym przez czynniki zewnętrzne. Ojciec Honorat swą koncepcję życia zakonnego wpisał w ówczesną sytuację polityczną, w której powstawały zgromadzenia ${ }^{8}$. Owa sytuacja społeczno-polityczna XIX wieku znana jest z wielu źródeł historycznych. Dla nas szczególne znaczenie ma obraz rzeczywistości życia zakonnego. Proces likwidacji klasztorów na ziemiach polskich zapoczątkowany pod koniec XVIII wieku, szczególnie nasilił się w wieku XIX i posiadał wiele wymiarów: społeczny, ekonomiczny, polityczny, religijny i kulturowy. Po upadku powstania styczniowego, w zaborach rosyjskim i pruskim, zaostrzył się kurs antypolski, a wobec Królestwa Polskiego władze carskie zastosowały politykę bezwzględnej unifikacji i rusyfikacji kraju. Polityka zaborcza zmierzała zdecydowanie do podporządkowania sobie Kościoła katolickiego. Powołany w 1864 r. Komitet Urządzający pod kierownictwem namiestnika Fiodora Fiodorowicza Berga miał na celu urządzenie polityczne kraju. Nowy aparat urzędniczy prawie całkowicie objęli Rosjanie przysłani z Cesarstwa Rosyjskiego. Unifikacja polityczna caratu nie ograniczała się tylko do zmian administracyjnych, ale sięgała także w głąb życia narodu. Niszczono kulturę polską, rusyfikowano kraj. Zakazano zajmowania się na łamach prasy sprawami politycznymi Królestwa Polskiego, a także sprawami kultury ogólnonarodowej. Uniemożliwiano tworzenie odrębnych stowarzyszeń naukowych, kulturalnych, a nawet gospodarczych. Dotkliwą klęską dla kultury ogólnonarodowej było hamowanie rozwoju szkolnictwa ${ }^{9}$.

\footnotetext{
${ }^{7}$ H. K o ź m i ń s k i, O zgromadzeniach ukrytych przed światem, Kraków [1901], s. 9; K. S y n o w c z y k, Obecność ukryta na podstawie pism bł. Honorata Koźmińskiego, s. 10. ${ }^{8}$ Por. A. Jakubczyk, Zgromadzenie Stug Jezusa $w$ społeczeństwie polskim w latach 1884-1939, Warszawa 2001, s. 45-50; 211-216; K. S y n o w c z y k, Obecność ukryta na podstawie pism bł. Honorata Koźmińskiego, s. 16.

${ }^{9}$ Por. S. K i e n i e w i c z, Historia Polski (1795-1918), Warszawa 1968, s. 299-300; M. H. M a z u re k, Powstanie i rozwój ukrytych zgromadzeń bt. Honorata Koźmińskiego w latach 1874-1908, Sandomierz 2009, s. 33n.
} 
W latach 1861-1864 w Królestwie Polskim odbywały się masowe manifestacje patriotyczne, połączone $\mathrm{z}$ nabożeństwami w intencji Ojczyzny nazwane rewolucją moralną, angażujące w sporym stopniu duchowieństwo diecezjalne i zakonne - także kapucynów. Były one swoistym przygotowaniem duchowym do uzyskania niepodległości lub przynajmniej większej autonomii politycznej. Głównym ośrodkiem wydarzeń rewolucji moralnej była Warszawa, ale także inne miejscowości Królestwa Polskiego. Zaangażowanie zakonników polegało głównie na głoszeniu kazań o treści patriotycznej i odprawianiu nabożeństw. Te ostatnie miały różny charakter, często były to msze św. za pomyślność ojczyzny, celebry żałobne za zmarłych, którzy uosabiali dążenia do odzyskania niepodległości (np. 23 II 1859 w warszawskim kościele kapucynów za poetę Zygmunta Krasińskiego). Dnia 10 czerwca 1861 r. nabożeństwo za zmarłego Joachima Lelewela celebrował w warszawskim kościele kapucynów bp Jan Dekert, sufragan warszawski. Świątynia kapucynów dała się poznać z nadawania patriotycznego rysu nabożeństwom majowym. Wierni gromadzili się przed iluminowaną figurą Matki Bożej stojącą przed kościołem, śpiewając nie tylko litanię czy pieśni maryjne, ale także śpiewy narodowe. Wykorzystywano nabożeństwa do śpiewania „zakazanych" pieśni: chodziło głównie o Boże, coś Polskę, i $Z$ dymem pożarów, odczytywane przez władze carskie jako śpiewy rewolucyjne ${ }^{10}$.

Geneza tworzenia zgromadzeń ukrytego życia zakonnego uwarunkowana była nie tylko sytuacją polityczną.

\section{Uwarunkowania społeczne}

Zlikwidowano Komisję Wyznań i Oświecenia Publicznego. Sprawy oświaty przejął Warszawski Okrąg Szkolny podległy wprost Ministerstwu Oświaty w Petersburgu. Królestwu Polskiemu odebrano jego nazwę i zmieniono na Kraj Przywiślański. Zakazano zakładania odrębnych

${ }^{10}$ Por. R. B e n d e r, Rewolucja moralna 1861 r., „Zeszyty Naukowe KUL” 4(1961), nr 3, s. 83-94; F. J. D u c h n i e w s k i, Polska Prowincja Kapucynów w XIX wieku (17951864), [w:] Zakony franciszkańskie w Polsce, pod red J. K ł o c z o w s k i e g o, t. 4, cz. 1, Lublin 1987, s. 73n; T e n że, Z dziejów polskiej Prowincji kapucynów (1810-1921), s. 55; R. P rej s, Zakonnicy franciszkańscy Królestwa Polskiego po kasacie 1864 r., [w:] W stużbie pokoju i dobra. Jubileusz pięćdziesięciolecia odrodzenia Warszawskiej Prowincji Kapucynów. Księga Pamiątkowa, pr. zbr. pod red. R. P r e j s, Warszawa 2002, s. 78. 80; Te nże, Kapucyni Prowincji Polskiej $w$ rewolucji moralnej $i$ powstaniu styczniowym, [w:] Życie zakonne w Królestwie Polskim w latach 1832-1864, s. 123n. 
stowarzyszeń gospodarczych, naukowych, kulturalnych i filantropijnych. Rozwiązano nawet Radę Dobroczynności w Warszawie. Język polski ograniczono do tego stopnia, że stał się on jednym z nadobowiązkowych przedmiotów nauczania w szkole. W 1865 r. nauczyciele otrzymali nakaz uczenia języka rosyjskiego, obok innych przedmiotów, a w lutym $1866 \mathrm{r}$. nakaz posługiwania się nim w korespondencji. Na zaistniały stan rzeczy społeczeństwo polskie odpowiedziało tajnym nauczaniem. W miastach organizowano tajne komplety oraz nieregularnie prowadzono szkoły. $\mathrm{Na}$ wsi zaś nauczanie dzieci odbywało się we dworach i na plebaniach. Kuratorium Warszawskiego Okręgu Szkolnego zlikwidowało jednak tajne nauczanie doprowadzając tym samym do wzrostu analfabetyzmu. Obok tego zjawiska powszechnym na wsi był alkoholizm. Jedynym centrum rozrywki wiejskiej, cieszącym się dużym powodzeniem były liczne karczmy, których właścicielami byli przeważnie Żydzi. Utrzymanie takiej sytuacji na wsi było w interesie władz zaborczych ${ }^{11}$.

Znaczny wpływ w dziedzinie społecznej i ekonomicznej wywarło powstanie styczniowe. Mimo porażki w walce o niepodległość, w zakresie reform społecznych pojawiło się uwłaszczeniowa chłopów, które doprowadziło do ostatecznej likwidacji struktur feudalnych na ziemiach polskich. Chłopi otrzymali prawo do użytkowanej przez siebie ziemi i mieli być zwolnieni z wszelkich powinności na rzecz dworu. Ukaz carski z 2 lutego 1864 r. pozornie tylko dawał uprawnienia chłopom, w rzeczywistości jednak nie rozwiązywał całkowicie sprawy agrarnej. Pomimo tego uwłaszczenie otworzyło perspektywy szybszego awansu gospodarczego Polski, a rozwój stosunków kapitalistycznych przyczynił się do upowszechnienia świadomości narodowej wśród mas. Odtąd zabór rosyjski wszedł w epokę rozwiniętego już kapitalizmu, która pod zaborami pruskim i austriackim zaczęła się znacznie wcześniej, po rewolucji 1848-1849 r. ${ }^{12}$.

Wśród uwarunkowań społecznych należy wskazać na program pozytywistów, którzy odrzucali wszelką metafizykę i postulowali wyłamanie się spod wpływów duchowieństwa. Po upadku powstania styczniowego,

\footnotetext{
${ }^{11}$ Por. K. L e m án s k a, Fenomen ukrytego życia zakonnego na przykładzie zgromadzeń założonych przez o. Honorata Koźmińskiego, Lublin 1995, s. 39.

12 Por. M. H. M a zure k, Powstanie $i$ rozwój ukrytych zgromadzeń bł. Honorata Koźmińskiego $w$ latach 1874-1908, oprac. i przygot. do druku H. I. S z u m i 1, Sandomierz 2009, s. 37; K. L e m án s k a, Fenomen ukrytego życia zakonnego na przykładzie zgromadzeń założonych przez o. Honorata Koźmińskiego, s. 40.
} 
kiedy słabła wiara Polaków w odzyskanie wolności drogą walk o niepodległość, rozwinął się nurt pracy organicznej oraz pracy u podstaw, mający na celu podniesienie poziomu gospodarczego i oświaty w kraju. Z ruchem tym korelował rozwój ukrytych zgromadzeń honorackich, które wychodziły naprzeciw oczekiwaniom Kościoła, który postulował ogólne podnoszenie poziomu religijnego ludu, zwłaszcza przez odrodzenie świadomości życia duchowego i czynienie miłosierdzia potrzebującym. Postulowano przyjęcie doktryny chrześcijańskiej w całości i oparcie na niej organizacji społeczeństwa w myśl zasady sprawiedliwości. Powoli zaczęto wcielanie zasad ewangelicznych do obyczajów, do instytucji i do praw, którymi rządzi się społeczeństwo. Ojciec Honorat był przekonany, że sytuacji społecznej i gospodarczej nie rozwiąże się inaczej jak tylko przez autentyczne spojrzenie na życie w „duchu Chrystusowym”. Uważał, że konsekwencją braku „ducha Chrystusowego” jest niesprawiedliwość społeczna: „Brak sprawiedliwości w prawach, które karzą ciężko biedaka, co kradnie z głodu [...]. Brak sprawiedliwości w zwyczajach, które [...] robotnika podtrzymującego swą pracą cały gmach społeczny każe traktować z lekceważeniem [...]. Brak sprawiedliwości w samych warunkach życia, szczególniej dla klasy robotniczej, na czym głównie teraz kwestia socjalna się opiera. Dwie rzeczy są tutaj uderzające: krzywda pracy i nadużycie własności"13.

Następnym problemem społecznym, który Błogosławiony z Białej Podlaskiej boleśnie przeżywał, była emancypacja kobiet. Sprawa tego ruchu społecznego w drugiej połowie XIX w. była zasadnicza. Kobiety $\mathrm{z}$ różnych powodów musiały wejść w życie społeczne i to zarówno ze środowiska szlacheckiego, jak i mieszczańskiego, wiejskiego i robotniczego. Szczególnie kobiety ze środowiska wiejskiego nie zawsze była przygotowana ani zawodowo ani duchowo do podjęcia pracy w nowym środowisku. Stąd też były wykorzystywane przez pracodawców i niejednokrotnie upadały moralnie. Słabe duchowo gubiły się w nowych warunkach, którym nie potrafiła sprostać. Z powodu braku

${ }^{13}$ H. Koźmiński, Odpowiedź na ankiete „Przegladu Powszechnego”: Jakie sa szczególniejsze zadania, które katolicyzm u nas $w$ Polsce ma dzisiaj do spetnienia?, „Przegląd Powszechny” 90(1906), s. 20-21; K. Le m ańs k a, Fenomen ukrytego życia zakonnego na przykładzie zgromadzeń założonych przez o. Honorata Koźmińskiego, s. 34. 41; B. S z e w c z u 1, Dziatalność zakonodawcza błogosławionego Honorata Koźmińskiego a nowe instytuty w Kościele katolickim. Studium prawnohistoryczne, Warszawa 2008, s. 75. 
przygotowania zawodowego nie mogły wydajnie pracować. Ochrona i animacja duchowa kobiet szczególnie zaważyło na rozwoju zgromadzeń żeńskich tego okresu ${ }^{14}$.

Społeczne zaangażowanie zgromadzeń założonych przez o. Honorata widoczne stało się w rozmachu prowadzonego przez nie apostolatu. Ich działalność, obejmująca całokształt ówczesnego życia społecznego, określa się mianem ruchu honorackiego, czyli ogółu inicjatyw zgromadzeniotwórczych bł. Honorata Koźmińskiego. Inicjatywy te rodziły się przy kratkach konfesjonału, gdzie spotykał się z ogromną rzeszą ludzi. Myślał, przede wszystkim o tych kobietach, w których dostrzegał zapał apostolski i prawdziwe powołanie zakonne. Nie chciał ich kierować do klasztorów zagranicznych, aby nie pozbawić kraju ludzi gorliwych. Dlatego zalecał dążenie do doskonałości w warunkach, w jakich się znajdowały. Z czasem, gdy gromadziły się wokół jego konfesjonału osoby pochodzące $\mathrm{z}$ różnych środowisk społecznych, zaczął tworzyć z nich odpowiednie grupy apostolskie i odsyłał tam, skąd pochodziły, by dawały świadectwo o Bogu. Po pewnym czasie grupy te dały początek zgromadzeniom, które wyrastały z konkretnego zapotrzebowania na pracę $\mathrm{w}$ danym środowisku społecznym. Tworzące się zgromadzenia były zaczynem ewangelicznym dla wzrostu istotnych wartości życia religijnego i patriotycznego narodu ${ }^{15}$.

W tym kontekście należy podkreślić ważną cechę duchowości jaką jest apostolstwo, które staje się zrozumiałe jako przejaw duchowości eklezjalnej. Podobnie jak św. Franciszek, jego naśladowcy pragnęli poświęcić wszystkie swoje siły dla ratowania dusz ludzkich, dla których tak wiele uczynił Zbawiciel. Nie można żyć duchem miłości bez całkowitego poświęcenia się dla zbawienia bliźnich. Pomocą są szczególne charyzmaty udzielone przez Boga, których efekty widoczne stają się u samego obdarzonego i jego najbliższego otoczenia. Twórcze podejście do charyzmatów, których Bóg udziela konkretnym osobom będących ich odbiorcą,

\footnotetext{
${ }^{14}$ Por. K. L e m án s k a, Fenomen ukrytego życia zakonnego na przykładzie zgromadzeń założonych przez o. Honorata Koźmińskiego, s. 44.

${ }^{15}$ Zob. H. K o ź m iń s k i, Wiadomości o zgromadzeniach prowadzacych życie ukryte przed światem, [w:] Wybór pism o. Honorata Koźmińskiego, cz. 5, Polskie teksty ascetyczne, t. XI, Warszawa 1988, s. 11-12; por. K. L e m a ń s k a, Fenomen ukrytego życia zakonnego na przykładzie zgromadzeń założonych przez o. Honorata Koźmińskiego, s. 44; B. S z e w c z u 1, Działalność zakonodawcza błogosławionego Honorata Koźmińskiego a nowe instytuty $w$ Kościele katolickim, s. 77.
} 
poprzez te osoby owoce ich działalności udzielają się innym ludziom. Wokół charyzmatów rodzi się pewna duchowość czyli konkretny sposób przyłączenia się do Jezusa Chrystusa w ramach misji eklezjalnej ${ }^{16}$.

Przemiany społeczno-ekonomiczne dokonujące się już w początkach XIX wieku postawiły Kościół katolicki wobec konieczności szukania nowych form apostolatu i metod pracy duszpasterskiej. Charakterystycznym i na ogół znanym zjawiskiem tegoż stulecia jest dążenie do odnowy życia zakonnego w starych formach oraz powstanie i szybki rozwój zgromadzeń, zwłaszcza żeńskich, z wyraźnie sprecyzowanym programem społeczno-apostolskim ${ }^{17}$. Najaktywniejszą grupę inicjatorów i kierowników nowych kongregacji zakonnych stanowili kapucyni Królestwa Polskiego. W latach pięćdziesiątych XIX w. kapucyńskie klasztory zaboru rosyjskiego - szczególnie warszawski - przeżywały okres własnego odrodzenia. W opinii publicznej, w okresie poprzedzającym powstanie styczniowe, kapucyni uchodzili za najgorliwszy zakon. Działalność ich wiąże się z polskim ruchem zakonnym, nastawionym na aktualne potrzeby społeczne ${ }^{18}$.

\section{4. Życie zakonne}

Zaangażowanie zakonników w wydarzenia rewolucji moralnej nie było obojętne dla władz państwowych. Obwiniały ich o wpływ na społeczeństwo i solidaryzowanie się z nim w demonstracjach. Udział duchowieństwa w manifestacjach patriotycznych w latach 1860-1862 oraz bezpośrednie i pośrednie uczestnictwo w powstaniu styczniowym stał się powodem podjęcia represji. Pojawiły się szczegółowe dyrektywy rządowe krępujące normalną swobodę działania zakonów. Aktywniejszych karały grzywną lub nawet więzieniem. Najbardziej jednak zaangażowani zakonnicy zostali zesłani w głąb Rosji. Ich sytuacja, podobnie jak wszystkich zesłańców, mogła być trojaka. Zesłani na katorgę byli pozbawieni wszelkich praw stanu i kierowano ich najczęściej do pracy

\footnotetext{
${ }^{16}$ Por. ŚFS, t. 4, s. 440; por. M. C h m i e l e w s k i, Duchowość wedtug Jana Pawła II, s. 71; F. C i a r d i, Koinonia. Itinerario teologico-spirituale della comunità religiosa, Roma 1992, s. 59n.

17 Por. E. J a błońs k a - D e p tuła, Polskie odrodzenie religijne $w$ XIX wieku, „Więź” 3(1960), nr 5, s. 53-70; M. H. M a zur e k, Powstanie i rozwój ukrytych zgromadzeń bt. Honorata Koźmińskiego w latach 1874-1908, s. 51.

${ }^{18}$ Por. M. H. Mazur e k, Powstanie i rozwój ukrytych zgromadzeń bł. Honorata Koźmińskiego w latach 1874-1908, s. 54.
} 
w kopalniach lub niektórych zakładach przemysłowych, niekiedy do innych prac fizycznych. Zesłani na osiedlenie nie byli kierowani do prac przymusowych, byli jednak - podobnie jak katorżnicy - pozbawieni praw, co w wypadku duchowieństwa oznaczało zakaz spełniania funkcji kapłańskich. Zesłani na zamieszkanie w odległych guberniach Rosji byli wolnymi obywatelami, mającymi tylko ograniczone miejsce zamieszkania do określonych guberni lub miejscowości ${ }^{19}$.

Specjalne komisje rządowe wypracowały szczegółowe normy prawne dla kasaty klasztorów. Podlegały jej te klasztory, którym stawiano co najmniej jeden z siedmiu zarzutów. Dotyczyły one: 1) namowy do udziału w powstaniu, odbieranie przysięgi od powstańców, ich rozgrzeszanie itp.; 2) ukrycia przez zakonników i przeora informacji o dokonanych w pobliżu klasztorów przestępstwach i dopuszczenie do ich zajść; 3) przystąpienia do „band” powstańczych i niepowiadomienie o tym władz; 4) zbierania pieniędzy na potrzeby powstania; 5) składania powstańczego podatku; 6) wykrycia na terenie klasztoru lub ziemiach zakonnych składów broni, amunicji, drukarni, wezwań i proklamacji rządu powstańczego; 7) ukrywania powstańców i udzielanie im pomocy np. lekarskiej. Przygotowany w tajemnicy dekret rozróżniał klasztory: „,zniesione" - w których znajdowało się mniej niż 8 zakonników, ,zamknięte” - te, których członkowie brali jawny i udowodniony udział w powstaniu, „nieetatowe”, czyli nadliczbowe - przeznaczone do zniesienia w miarę zmniejszania się stanu personalnego i „etatowe” (zatwierdzone przez władze carskie) - posiadające limit personalny od 14 do 24 zakonników, którym zapewniono pensje rządowe. Lącznie w Królestwie Polskim za etatowe uznano 35 klasztorów (25 męskich i 10 żeńskich), w których przebywało 360 zakonników i 140 sióstr zakonnych ${ }^{20}$.

19 Zob. Tekst Dziennik Praw Królestwa Polskiego, t. 62, 1864, 192, s. 407n; por. P. T a r n a w s k i, La direzzione spirituale nelle vita consecrata femminile secondo il beato Onorata Koźmiński, Roma 2007, s. 27-36; R. P r e j s, Zakonnicy franciszkańscy Królestwa Polskiego po kasacie 1864 r., s. 75; E. N i e b e ls ki, Duchowieństwo lubelskie $i$ podlaskie $w$ powstaniu 1863 roku $i$ na zesłaniu $w$ Rosji, Lublin 2002, s. 100-101; E. K a c z y ń s k a, Ludzie ukarani. Więzienia i system kar w Królestwie Polskim 1815-1914, Warszawa 1989, s. 42-134; S. W i e c h, Kasata klasztorów w Królestwie Polskim w 1864 r. w świetle wspomnień i relacji Dmitrija Anuczina, [w:] Życie zakonne $w$ Królestwie Polskim $w$ latach 1832-1864, red. W. G r a c z y k, J. M. M a r s z a 1 s k a, Kraków 2015, s. 14.

${ }^{20}$ Por. B. S z e w c z u 1, Działalność zakonodawcza błogosławionego Honorata Koźmińskiego a nowe instytuty w Kościele katolickim, s. 58; P. P. G a c h, Kasaty zakonów 
Oficjalną potrzebę kasat uzasadniano zbyt małą liczba zakonników w klasztorach, niewłaściwym zarządzaniem dobrami ruchowymi, rozkładem życia duchowego, a nawet szkodliwością społeczną. Paradoksem kasaty klasztorów w 1864 r. było, że władze państwowe, zarzucały im, iż zakonnicy zaniedbują sprawy należące do ich powołania. Patrząc z punktu widzenia carskiego zakonnicy Królestwa Polskiego rzeczywiście przez zaangażowanie powstańcze stawali niekiedy w opozycji do wymagań reguł zakonnych. Za udział w „,buncie” przeciwko prawowitej władzy, czyli w powstaniu styczniowym, car postanowił takie urządzenie życia zakonnego w Królestwie Polskim, by zakonnicy w przyszłości zajęci byli wyłącznie wypełnianiem obowiązków płynących z ich powołania. Sprzyjać temu miało ścisłe zastosowanie przepisów Soboru Trydenckiego o życiu zakonnym, w szczególności tych, które normowały liczbę zakonników w pojedynczym klasztorze oraz poddanie klasztorów jurysdykcji ordynariusza miejsca wzorem praktyki stosowanej w innych krajach. Biskupi natomiast i administratorzy diecezji, którzy na mocy ukazu z 1864 r. mieli stać się zwierzchnikami zakonników, nie radzili sobie $\mathrm{z}$ tą władzą, która spadła na nich nieoczekiwanie. Ani się jej nie spodziewali, ani nie pragnęli, ponieważ na problemach zakonnych się nie znali. Zniesienie urzędów prowincjałów, a także definitorów i kustoszów, oraz zakaz kontaktów z generałami rezydującymi poza granicami Królestwa Polskiego, oznaczały zniesienie zwierzchnich władz zakonnych, a w praktyce zniesienie pojęcia zakonu i zastąpienie go pojęciem klasztoru, bynajmniej nie równoważnym ${ }^{21}$.

Ukaz cara Aleksandra II z 8 listopada (27 października starego stylu) 1864 nazwany był ukazem o reformie klasztorów, a w ramach tejże „reformy” dokonywał on faktycznie kasaty klasztorów, zaś życie zakonne w Królestwie Polskim reorganizował w istotny sposób. Car powoływał się na przepisy Kościoła, zakazujące istnienia klasztorów nie mających wystarczającej liczby zakonników oraz takich, w któ-

na ziemiach dawnej Rzeczpospolitej i Ślaska 1773-1914, Lublin 1984, s. 175-184; F. J. D u chn i e w s k i, Z dziejów polskiej Prowincji kapucynów (1810-1921), s. 57; $\mathrm{S}$. W i e c h, Kasata klasztorów w Królestwie Polskim w 1864 r. w świetle wspomnień i relacji Dmitrija Anuczina, s. 20.

${ }^{21}$ Por. R. P r e j s, Zakonnicy franciszkańscy Królestwa Polskiego po kasacie 1864 r., s. 88n. 352; M. M. Gr z y b o w s k i, Postawa Wincentego Chościak-Popiela, biskupa płockiego, wobec kasaty klasztorów z 1864 r. w jego diecezji, „Studia Płockie” 11(1983), s. 257-258. 
rych nie można zachować niezbędnej dyscypliny. Według tych założeń skasowane zostały klasztory, w których przebywało mniej, niż 12 zakonników, klasztory położone na terenach o przewadze ludności unickiej lub prawosławnej oraz te, których członkowie angażowali się w działania powstańcze. Przyjmowanie nowych kandydatów ograniczono tylko do synów szlacheckich oraz obwarowano koniecznością uzyskania uprzedniego pozwolenia ministra spraw wewnętrznych. Nowicjat miał trwać trzy lata, a śluby zakonne można było składać po ukończeniu 22 roku życia. Utrzymanie klasztorów miało być finansowane $\mathrm{z}$ wypłacanych przez państwo pieniędzy pochodzących z zabranych majątków kościelnych. Zakazano udawania się na kwestę. Klasztory, pozbawione środków materialnych, możliwości przyjmowania nowych kandydatów oraz prowadzenia jakiejkolwiek działalności apostolskiej i wpływu na wiernych, skazane zostały na wymarcie ${ }^{22}$.

Sprawa źródeł utrzymania stała się powodem zamknięcia zgromadzenia sióstr felicjanek. Pretekstem likwidacji tego zgromadzenie były kwestie formalne, gdyż ,nie przedłożyło ono w wyznaczonym terminie do 3 czerwca 1859 r. ustawy do zatwierdzenia przez władze państwowe i nie wykazało źródeł swego utrzymania. Odpowiedzialnym za likwidację zgromadzenia w Warszawie, którą dokonano 17 grudnia, był płk Annenkow. Wczesnym rankiem do klasztoru wkroczyło siedmiu urzędników rosyjskich, z których jeden odczytał siostrom zebranym w wielkiej sali ukaz carski rozwiązujący zgromadzenie. Siostry miały zrzucić habity i w ciągu trzech dni rozejść się do rodzin czy innych domów prywatnych. Z klasztoru 19 sióstr felicjanek klauzurowych pod konwojem wojskowo-policyjnym przywieziono do Łowicza do klasztoru sióstr bernardynek. Pozostałe siostry, zgodnie z instrukcją namiestnika rozdzielono w następujący sposób: 83 powróciły do życia świeckiego, pozostając w Warszawie przy swoich rodzinach, 15 wysłano za granicę, 5 wyjechało do rodzin w Cesarstwie, 46 otrzymało paszporty na opuszczenie Warszawy i udanie się do swoich rodzin zamieszkałych w innych guberniach Królestwa polskiego. Ponieważ felicjanki

\footnotetext{
${ }^{22}$ Por. S. G a j e w s k i, Kasata klasztorów w diecezji lubelskiej w roku 1864, „Roczniki Humanistyczne" 21(1972), nr 1-2, s. 355-359; P. P. G a c h, Kasaty zakonów na ziemiach dawnej Rzeczpospolitej i Ślaska 1773-1914, s. 150-170; R. P r e j s, Zakonnicy franciszkańscy Królestwa Polskiego po kasacie 1864 r., s. 97; B. S z e w c z u 1, Działalność zakonodawcza blogosławionego Honorata Koźmińskiego a nowe instytuty w Kościele katolickim, s. 61.
} 
oskarżone były o prowadzenie ożywionej agitacji wśród unitów, stąd też poddane zostały surowemu nadzorowi policji ${ }^{23}$.

Kryzys, który dotykał zakony w Królestwie Polskim w przededniu kasaty, nie ustał po 1864 r., ale się nasilił. Likwidacja większości klasztorów, wyrwanie $\mathrm{z}$ dotychczasowych środowisk i miejsc pracy, przymusowe przejście pod jurysdykcję ordynariuszów miejsca, zniesienie dotychczasowych urzędów zakonnych, zakaz przyjmowania nowicjuszów wszystko to sprzyjało dezintegracji wspólnot zakonnych, których członkowie w zaistniałej sytuacji czuli się zagubieni, niepewni jutra i tym łatwiej bądź poddawali się słabością, bądź szukali okazji do ułożenia sobie życia poza zakonem. Dotyczyło to nie tylko zakonników nieustabilizowanych w powołaniu lub czujących się źle w klasztorze, lecz także poważnych, miłujących - zdawałoby się - życie zakonne i odznaczających się w innych sprawach godną postawą. Kasata bezlitośnie obnażyła słabości wielu zakonników, w szczególności niski poziom formacji uzyskanej w nowicjacie i w pierwszych latach życia zakonnego, nieznajomość wymagań Kościoła co do ślubów zakonnych, a często swoiste rozumienie tychże ślubów, rozkład życia wspólnego połączony z przeakcentowaniem pracy duszpasterskiej poza klasztorami, brak umiłowania życia zakonnego. Na podkreślenie zasługują więc ci zakonnicy, którzy czynili wszystko, by do śmierci wytrwać w powołaniu zakonnym. Przechowała się informacja, że u kapucynów w Zakroczymiu na propozycję przejścia do pracy parafialnej o. Honorat Koźmiński miał publicznie odpowiedzieć: „Żaden nie wyjedzie! Tu nas Pan Bóg chce mieć, a więc tu pracować będziemy"24. W tym klasztorze, oprócz Błogosławionego znaleźli się zakonnicy przybyli z Warszawy, obstający za praktykowaniem surowej obserwancji. Okazuje się, że dobra formacja zakonna otrzymana $\mathrm{w}$ ramach reformy kapucyńskiej pomagała pokonać nawet ograniczenia wieku i zdrowia. Bł. Honorat informował generała zakonu, że kapucyni w klasztorze w Nowym Mieście pilnują chóru, choć nie

\footnotetext{
${ }^{23}$ Por. S. W i e c h, Kasata klasztorów w Królestwie Polskim w 1864 r. w świetle wspomnień i relacji Dmitrija Anuczina, s. 32; D. K o s k a, Życie ukryte przed światem. Dzieje klarysek kapucynek z Przasnysza - 150 lat istnienia zakonu, Pelplin 2017, s. 83n.

24 M. W e rn e r, O. Honorat Koźmiński Kapucyn 1829-1916, Poznań-Warszawa 1972, s. 81-82; por. B. D m o w s k a, Matka Maria Angela Truszkowska Założyciela Zgromadzenia Sióstr Felicjanek (1825-1899), t. 1. Życiorys, Buffalo N.Y., 1949, s. 21; D. K o s k a, Życie ukryte przed światem, s. 81; R. P r e j s, Zakonnicy franciszkańscy Królestwa Polskiego po kasacie 1864 r., s. 203.
} 
praktykują odmawiania brewiarza nocą. Kapucyni w pokasacyjnej rzeczywistości nie załamali się i nie ulegli pokusie łatwiejszego ułożenia sobie egzystencji, lecz heroicznie trwali w ślubowanym sposobie życia. Było to owocem formacji jaką otrzymali w ramach reform przeprowadzonych przez o. Beniamina Szymańskiego ${ }^{25}$.

\section{Reformy kapucyńskie}

Po okresie wojen napoleońskich niemal wszystkie zakony podjęły wysiłek zmierzający do odrodzenia duchowego, ożywienia gorliwości w zachowywaniu reguły i znalezienia nowych metod oddziaływania duszpasterskiego. Wysiłek ten spotkał się z przychylnością Stolicy Apostolskiej, a nawet w znacznym stopniu był przez nią inspirowany, co znalazło wyraz w encyklice Piusa IX Ubi primum arcano z 17 kwietnia 1847 r., w której polecał odnowić karność i podnieść poziom kształcenia zakonników. Papież wezwał więc zakony do rozpoczęcia wielkiego dzieła reformy ${ }^{26}$. Wykonaniem tej długofalowej i szczegółowo zaplanowanej reformy miała się zająć nowo utworzona kongregacja. Powołana przez papieża Piusa IX we współpracy, a może nawet z inicjatywy włoskiego kapucyna o. Justusa Recanatti, późniejszego biskupa (1852 r.) i kardynała (1858 r.) nowa kongregacja De Statu Regularium Ordinum rozesłała do zakonów ankietę z propozycjami działań zmierzających do podniesienia karności zakonnej przez podniesienie wymagań $w$ formacji i właściwe jej ustawienie ${ }^{27}$.

Najbardziej skuteczną i owocną reformą była reforma kapucynów powzięta przez prowincjała Beniamina Szymańskiego w latach 18361849 i $1852-1856^{28}$. Reforma ta obejmowała sześć głównych kierunków. W zakresie życia modlitewnego było to przywrócenie wspólnego

${ }^{25}$ Por. H. K oźm i ń s k i, Pisma, t. 2, s. 63, 84-85, 92; por. R. Prej s, Zakonnicy franciszkańscy Królestwa Polskiego po kasacie 1864 r., s. 209.249.

${ }^{26}$ Por. F. J. D u c h n i e w s k i, Polska Prowincja Kapucynów, s. 65; R. P r e j s, Zakonnicy franciszkańscy Królestwa Polskiego po kasacie 1864 r., s. 63; Z. Z i e 1 i ń s k i, Papiestwo i papieże dwóch ostatnich wieków, Warszawa 1999, s. 206.

${ }^{27}$ Por. F. J. D u c h n i e w s k i, Z dziejów polskiej Prowincji kapucynów (1810-1921), [w:] W stużbie pokoju i dobra. Jubileusz pięćdziesięciolecia odrodzenia Warszawskiej Prowincji Kapucynów. Księga Pamiątkowa, pr. zbr. pod red. R. Pre j s, Warszawa 2002, s. 36.

${ }^{28}$ Por. E. J a b ł oń s k a - D e p t u ł a, J. G a w r ys i a k ow a, Z zagadnień religijnospołecznego ruchu kobiet w Królestwie Polskim połowy XIX wieku, „Roczniki Humanistyczne" 18(1970), z. 2, s. 102. 
odmawiania brewiarza z Matutinum o północy, z czego nie zwalniała nawet praca duszpasterska. Dawano więc prymat modlitwy nad duszpasterstwem. Powrócono do praktyki dwóch godzin rozmyślania dziennie. Położył natomiast nacisk na życie wspólne, zachowanie zewnętrznych przejawów życia zakonnego, jak noszenie habitu, chodzenie w sandałach i golenie tonsur. Ojciec Beniamin wypowiedział zdecydowaną walkę pijaństwu wśród zakonników. Zabroniono podawanie alkoholu, najpierw częściowo, później całkowicie. Zakazano gromadzeniu prywatnych oszczędności, samowolnemu opuszczaniu klasztoru. Nakazano podróżowanie pieszo, co nie dotyczyło chorych oraz udających się w Wiatykiem lub innych pilnych sprawach duszpasterskich. W zakresie duszpasterstwa zreformowano praktykę prowadzenia misji, które powierzono grupie 4-8 zakonników, w skład której wchodzili kaznodzieje i spowiednicy. W następnej kolejności ożywiono zaangażowanie duszpasterskie w kościołach klasztornych, w szczególności zwracano uwagę na poziom głoszonych kazań, asystencję duchową grup religijnych i wprowadzenie nowych nabożeństw ${ }^{29}$.

Jednym z przejawów walki o obserwancję było przeprowadzenie przez Szymańskiego na kapitule prowincjalnej w 1845 r. uchwały, że nie będą dopuszczani do złożenia ślubów ci nowicjusze, którzy nie zobowiążą się do całkowitej abstynencji od alkoholu. W przezwyciężaniu wykroczeń o. Beniamin zaczynał zwykle od upomnień i wezwań do poprawy zawartych w listach okólnych, w następnej kolejności sięgał po kary wobec winnych, poczynając od upomnień, poprzez suspensę, aż po degradację i karne wydalenie $\mathrm{z}$ zakonu ${ }^{30}$.

Dodatkowym środkiem mobilizującym zakonników do większej wierności było ustanowienie klasztorów w Lądzie i Lubartowie tzw. domami ścisłej obserwancji, w których wszystkie wymagania ustaw zakonnych zachowywano w całej rozciągłości, bez najmniejszych dyspens czy złagodzeń ${ }^{31}$. W zakresie wychowania i kształcenia młodych

\footnotetext{
${ }^{29}$ Por. F. J. D u c h n i e w s k i, Polska Prowincja Kapucynów, s. 108-128; R. P r e j s, Zakonnicy franciszkańscy Królestwa Polskiego po kasacie 1864 r., s. 74; J. M a re c k i, R. P r ej s, Zarys historii kapucynów w Polsce, Kraków 2004, s. 77.

${ }^{30}$ Por. F. J. D u c h n i e w s k i, Polska Prowincja Kapucynów, s. 108-128; R. P r e j s, Zakonnicy franciszkańscy Królestwa Polskiego po kasacie 1864 r., s. 75; J. M a r e c k i, R. P r ej s, Zarys historii kapucynów w Polsce, s. 77.

${ }^{31}$ Por. F. J. D u c h n i e w s k i, Polska Prowincja Kapucynów, s. 108-128; R. P r e j s, Zakonnicy franciszkańscy Królestwa Polskiego po kasacie 1864 r., s. 75.
} 
zakonników postawiono wymóg znajomości łaciny w zakresie brewiarza. Biblioteki w domach studiów miały być zaopatrzone w podręczniki do nauki. Przywrócono praktykę rozwiązywania kazusów oraz egzaminów na patent kaznodziejski i jurysdykcyjny, a od lektorów żądano biegłej znajomości filozofii i teologii. Był to powrót do teologii duchowości średniowiecznej a zwłaszcza do kontynuatorów myśli św. Bonawentury. Najbardziej odpowiadała kapucynom postać J. Gersona, który był wyśmienitym kaznodziejom i kontynuatorem myśli mistycznej św. Bonawentury. Celem całego wysiłku formacyjnego było ukształtowanie kapucyna jako kaznodziei i mistyka. Kaznodziejstwo może być skuteczne tylko wtedy, gdy będzie wypływać z kontemplacji. Zaś doskonała miłość Boga i bliźniego, pokora, wysiłki ascetyczne domagały się skorzystania z myśli teologicznej św. Augustyna i św. Bernarda. Kapucyni korzystali również z inspiracji francuskiej szkoły duchowości kard. Pierra de Berulle'a i jej kontynuatorów tj. Ludwika Marii Grigniona de Montforta, Jana Eudes'a, Alfonsa Marii de Liguori, Fredericka Williama Fabera ${ }^{32}$. Z działalności o. Beniamina wyrosło pokolenie kapucynów, żyjące i działające w okresie po powstaniu styczniowym. Pomimo trudnych warunków swoje oddziaływanie duszpasterskie i formacyjne prowadzili poprzez apostolstwo słowa drukowanego, liczne przekłady na język polski dzieła mistrzów życia duchowego, pisanie traktatów teologicznych i rekolekcji duchowych, kierownictwo duchowe zarówno w konfesjonale jak i korespondencyjne, działalność zakonotwórczą. Sytuacja społecznopolityczna uniemożliwiała głoszenia kazań, prowadzenia misji, rekolekcji, dlatego kapucyni rozpoczęli pracę literacką, aby poprzez słowo pisane dotrzeć do jak najszerszych warstw społecznych ${ }^{33}$.

Wśród duszpasterzy warszawskich wyróżniał się młody o. Honorat Koźmiński. Oprócz licznych i odpowiedzialnych obowiązków, które spełniał w klasztorze warszawskim, wkrótce po otrzymanych święceniach, rozwinął szeroką działalność, włączając się w ogólny nurt życia

32 Por. W. P i ot row s ki, Wybór kazań niedzielnych, świątecznych i przygodnych, t 1-4, Warszawa 1840; T e n że, Kazania w osobliwszych materiach (rkp), [w:] Biblioteka Warszawskiej Prowincji Kapucynów w Zakroczymiu (dalej: BWP); T e n że, Przemówienia zakonne (1813-1835), t. 1-3 (rkp), [w:] BWP; J. Marecki, R. P r e j s, Zarys historii kapucynów w Polsce, s. 76n.

${ }^{33}$ Por. R. Prej s, Kapucyni Prowincji Polskiej po kasacie 1864 r. Losy-postawy, „Studia Franciszkańskie” 8(1997), s. 283-345. 
społecznego. Najbardziej rozległym i praktycznie najdonioślejszym terenem pracy apostolskiej dla Błogosławionego była działalność w III Zakonie św. Franciszka, istniejącym od dawna przy warszawskim kościele kapucynów. W ciągu dziesięcioletniej działalności o. Honorata przy ul. Miodowej do tercjarstwa wstąpiło 511 nowicjuszek, z tego 425 przyjął on sam. Na mocy otrzymanych uprawnień, o które postarał się u Generała Zakonu w 1859 roku, utworzył z tercjarek świeckich kongregację. Z ruchem zreformowanego tercjarstwa wzięło początek Zgromadzenie Sióstr św. Feliksa, zwane powszechnie felicjankami. Idei zgromadzeń ukrytych należy doszukiwać się już w fakcie kasaty warszawskiego klasztoru tegoż Zgromadzenia, ponieważ siostry skierowane każda do miejsca swojego urodzenia, nie mogły prowadzić życia wspólnego, wspólnie się modlić, ani nosić habitu. Zachęcał do założenia świeckich sukien, jeżeli niemożliwe okaże się noszenie habitów. Przekonywał, że nawet bez klasztoru i bez habitu także można być osobą zakonną ${ }^{34}$.

\section{Tercjarstwo franciszkańskie}

Wprowadzony przez o. Honorata w Warszawie podział grup wiernych na kongregacje i bractwa w ramach III Zakonu oraz kół żywego różańca powoli prowadził go do podjęcia decyzji o utworzeniu zgromadzeń zakonnych prowadzących życie ukryte. Sprzyjała temu organizacja tercjarstwa franciszkańskiego, którym kierował w Warszawie, gdzie formacja członków opierała się na instytucjach bardzo zbliżonych do istniejących w zakonach. Znane były: nowicjat, składanie profesji, urząd przełożonych, wizytacje, odmawianie określonych modlitw, zachowanie Reguły. Trafnie zauważył Błogosławiony, że dziewiętnastowieczny ruch powrotu do duchowości św. Franciszka, zainicjowany przez papieża Leona XIII,

\footnotetext{
${ }^{34}$ Zob. H. K o ź m i ń s k i, Wiadomości o nowych zgromadzeniach zakonnych powstatych w tym wieku w różnych krajach katolickich. Ttumaczenie z francuskiego, Kraków 1890, s. 10; por. B. S z e w c z u 1, Działalność zakonodawcza błogosławionego Honorata Koźmińskiego a nowe instytuty $w$ Kościele katolickim, s. 70; E. J a bło ń s k a De p tuła, Przystosowanie $i$ opór. Zakony męskie $w$ Królestwie Kongresowym, Instytut Wydawniczy PAX, Warszawa 1983, s. 272; M. H. M a z u re k, Powstanie i rozwój ukrytych zgromadzeń bł. Honorata Koźmińskiego w latach 1874-1908. Opracowała i przygotowała do druku Halina Irena S z u m i ł, Sandomierz 2009, s. 57-60; K. Le mańs ka, Fenomen ukrytego życia zakonnego na przykładzie zgromadzeń założonych przez o. Honorata Koźmińskiego, Lublin 1995, s. 43.
} 
objawiał się nie tylko w piśmiennictwie, ale i w czynach. W ciągu tych wieków III Zakon kształtował i rozwijał się w dwóch konfiguracjach: „świeckim” i „regularnym”, czyli zakonnym. Reguła papieża Mikołaja IV dla tercjarzy świeckich była aktualna i obowiązywała do 1883 r., natomiast dla tercjarzy zakonnych tak mężczyzn, jak i niewiast była aktualna od 1521 r. do 1927 r. $^{35}$. W 1521 r. papież Leon X, konstytucją Inter caetera, zreformował Regułę zatwierdzoną przez papieża Mikołaja IV, skrócił ją do dziesięciu rozdziałów i dostosował do potrzeb tercjarzy i tercjarek, pragnących żyć według rad ewangelicznych w zgromadzeniach zakonnych przez złożenie trzech ślubów: posłuszeństwa, czystości i ubóstwa. Widzimy więc, że w XIX wieku obowiązywały dwie Reguły. Tercjarstwo, zostało ożywione i znalazło się liczne grono osób, które z podobnym zapałem, jak to było za czasów serafickiego świętego, poświęciło się na służbę Bogu i bliźnim. Papież Leon XIII, który w encyklice Auspicato, z dnia 17 września 1882 roku, zachęca do zgłębienia duchowości franciszkańskiej. Sam będąc tercjarzem franciszkańskim, utrzymywał, że św. Franciszek i Jego Trzeci Zakon jest „najskuteczniejszym środkiem do odrodzenia dzisiejszego świata”. Ruch tercjarski miał być także odpowiedzią i lekarstwem na rozwijające się liczne - wrogie Kościołowi - stowarzyszenia XIX wieku ${ }^{36}$.

Błogosławiony mocno podkreśla, że III Zakon nigdy jeszcze nie był tak popularny, co należy uważać za nowe objawienie Boże. Ten znak czasu, jeżeli nie w cudowny, to w bardzo zadziwiający sposób, został okazany w drugiej połowie XIX wieku. Stał się wskazówką, że ma dokonać się wielkie odrodzenia świata w tymże duchu. O. Honorat dostrzegał wyraźne podobieństwo między epoką św. Franciszka a sytuacją społeczno-moralną XIX wieku. Dostrzegał ogólne odejście ludzkości od zasad chrześcijańskich, wyszydzanie Ewangelii i bluźnierstwa ze wszystkiego, co święte. Był przekonany, że zmianę sytuacji

35 Por. R. Pazzelli, San Fracesco e il Terz'Ordine, Padova 1982, s. 272; M. H. M a z u r e k, Powstanie i rozwój ukrytych zgromadzeń bł. Honorata Koźmińskiego w latach 1874-1908, s. 116; J. R. B a r, Tercjarstwo franciszkańskie, Kraków 1945.

${ }^{36}$ Por. ŚFS, t. 1, 20-280; T e n ż e, Nauki o Trzecim Zakonie Ś.O. Franciszka, Warszawa 1920, s. 45; por. B. S z e w c z u 1, Działalność zakonodawcza błogosławionego Honorata Koźmińskiego a nowe instytuty w Kościele katolickim, s. 72; M. S z y m u 1 a, Duchowość zakonna wedlug pism bł. Honorata Koźmińskiego, Warszawa 1999, s. 236n; M. H. M a zu r e k, Powstanie i rozwój ukrytych zgromadzeń bł. Honorata Koźmińskiego w latach 1874-1908, s. 117. 
może przynieść zryw dokonany na miarę św. Franciszka. Uważał, że Biedaczyna z Asyżu najlepiej zgłębił Ewangelię. Nikt wcześniej nie czerpał z niej tak obficie, szczególnie do praktyki życia, jak on. Stąd jego duch seraficzny był doskonałym odbiciem ducha Ewangelii. Św. Franciszek pragnął, aby jego naśladowcy byli prawdziwymi uczniami Dobrej Nowiny. Tercjarstwo, podobnie jak dwa inne zakony franciszkańskie, było szkołą Ewangelii i wymagało zgodności myśli z postępowaniem. Bracia i siostry ćwiczyli się głównie w dwóch cnotach, tj.: sprawiedliwości i miłości. Cnoty te mają zasadniczy wpływ na życie społeczne i utrzymanie pokoju. Podstawowym celem członków III Zakonu było naśladowanie Chrystusa ukazane w Ewangelii, według przykładu św. Franciszka. Wszystko to, co jest wzniosłe, zaszczytne i porywające w Ewangelii jest właściwe duchowi serafickie$\mathrm{mu}^{37}$. Wyrazem autentycznej służby Bogu miała być miłość bliźnim, w tym także różnokierunkowa działalność społeczna i charytatywna. Tym samym uprzedził poczynania papieża Leona XIII, który jako gorący zwolennik III Zakonu św. Franciszka ${ }^{38}$, wydał 17 września 1882 r. specjalną encyklikę Auspicato concessum ${ }^{39}$. Duch chrześcijański, w sprzeczności z duchem świata jest duchem pokuty, zaparcia, pokornego poddania się prawowitej władzy, co właśnie jest treścią zakonów św. Franciszka. Główną ich misją jest utrzymanie tego ducha w sobie samym, rozwijać go i przelewać w masy ludu. Nawoływał w niej do ożywienia instytucji franciszkańskich jako najlepszego sposobu zaradzenia ówczesnym problemom, wskutek czego „kwitnąć też będzie wiara, pobożność i wszystkie cnoty chrześcijańskie; przełamana zostanie ta sprzeczna $z$ wszelkim prawem gonitwa za rzeczami doczesnymi [...]. Ludzie miłować się będą wzajemnie, a z ubo-

${ }^{37}$ Por. O. H o n o r a t, Miesiąc seraficzny: Miesiąc październik na cześć Ś. Franciszka, II C, t. 31 (mps), [w:] Biblioteka Warszawskiej Prowincji Kapucynów w Zakroczymiu, s. 3; T e n ż e, ŚFS, t. 4, s. 15; M. H. M a z u r e k, Powstanie i rozwój ukrytych zgromadzeń bt. Honorata Koźmińskiego w latach 1874-1908, s. 117n; por. R. P a zz e 11 i, San Fracesco e il Terz Ordine, s. 241-242; Il Terzo Ordine Francescano. Riflessioni di storia e di spiritualità, Roma 1970, s. 16-18.

${ }^{38}$ Leon XIII jeszcze jako biskup Perugii (1846-1878) wszelkimi środkami popierał III Zakon św. Franciszka i propagował jego zakładanie we wszystkich parafiach swojej diecezji. Por. L. I r i a r t e, Historia franciszkanizmu, Kraków 1998, s. 522.

${ }^{39}$ Zob. Encyklika „,Auspicato” papieża Leona XIII, [w:] Św. Franciszek z Asyżu i jego Trzeci Zakon (dokumenty ostatnich papieży), red. i tłum. J. B a r, Z. W ł o d a r c z y k, Wrocław-Kraków 1948. 
gimi i nieszczęśliwymi, którzy są obrazem Chrystusa, obchodzić się będą z należytym szacunkiem"

Ów duch w swojej istocie jest chrześcijański i ewangeliczny, a jego uniwersalizm sprawia, że nadaje się do wszystkich miejsc i czasów. Zakony franciszkańskie przynoszą wielkie korzyści każdej epoce, stąd gorące pragnienie i zalecenie papieża Leona XIII, aby przywrócić należne miejsce zakonom franciszkańskim w Kościele. W przedsięwzięciu tym chodzi o ożywienie ich duchem serafickim, który jest im najbardziej właściwy. Brak odpowiedniego ducha sprawia, że na niewiele przydaje się zachowanie zewnętrznych form i literalne wypełnianie przepisów w życiu tych zakonów. Potrzeba ożywić wszystko duchem serafickim św. Franciszka. Duch serafickiej miłości wzywa do służby, pochylenia się nad każdym, najbardziej ostatnim, a będąc dalekim od pustej krytyki i osądów, zobowiązuje do stawania w prawdzie o sobie, co powoduje, że naśladowca Biedaczyny z Asyżu nie stawia siebie wyżej od innych ${ }^{41}$.

Sięgając początków tego ruchu, trzeba zauważyć, że wielką nowością św. Franciszka, o niezwykłej doniosłości społecznej i duchowej, było tercjarstwo, poprzez które pozwalał on osobom świeckim na pewien typ życia modlitwy, miłości i pokuty, który zaspokajał pragnienie doskonałości i powrotu do Ewangelii, jakie odczuwali ci, którzy nie mogli porzucić świata. Odkrył Ewangelię nie tylko dla siebie. Przekonany o ewangelicznym powołaniu i kierujący się Ewangelią w różnych sytuacjach życiowych, chciał nią oświecać także tych, którzy pragnęli go naśladować. Swoim kaznodziejstwem przyczynił się do zdynamizowania zarówno ruchu pokutnego, jak i wielu pokutników, pociągając za sobą na drogę Ewangelii też innych wiernych. Podejmującym w XIX wieku regularne życie tercjarskie, w oparciu o nauczanie papieży Leona XIII i Pius X, o. Honorat i inni kapucyni mocno zalecali tercjarzom przede wszystkim pracę nad osobistym nawróceniem i uświęceniem. Omnia instaurare in Christo - wszystko odnowić w Chrystusie, co dokonuje się poprzez powrót do Ewangelii, ducha chrześcijańskiego i gorliwości pierwszych wieków ${ }^{42}$.

\footnotetext{
${ }^{40}$ Tamże, nr 22; por. ŚFS, t. 4, s. 14.

${ }^{41}$ Por. ŚFS, t. 4, s. 11. 15; por. K. S y n ow c z y k, Błogosławieni słudzy. Wokót Napomnień św. Franciszka z Asyżu, Kraków 2009, s. 94.

${ }^{42}$ Por. ŚFS, t. 4, s. 14; por. P. Ri vi, Francesco D`Assisi e il laicato del suo tempo. Le origini dell Ordine Francescano Secolare, Padova 1989, s. 119-170; A. M. P a ń -
} 


\section{Nowe nurty pobożności}

Początki wieku XIX w całym Kościele przyczyniły się do ożywczego rozbudzenia świadomości chrześcijan, oscylujących pomiędzy „traditio" a „renovatio”. W tym okresie z różnorakich i głębokich ruchów rozwojowych, postępu i odnowy wyłania się romantyzm. Przyciągał on grupy ludzi zdecydowanych, twórczych, pełnych energii pobudzającej do odrodzenia narodu, a w sposób pośredni współpracujących w dziele przebudzenia religijnego i duchowego. To pasjonujące poszukiwanie odnowy jest obecne we wszystkich przejawach religijności, podobnie jak w ruchach narodowościowych. Z tym też wiąże się zarówno odrodzenie prestiżu Kościoła jak i pragnienie nowych doświadczeń mistycznych oraz próby wcielania $\mathrm{w}$ nowe formy religijne odzyskanego obrazu ewangelicznego, przeżywanego jako wyraz Chrystusowej miłości ${ }^{43}$.

Odrodzenie religijne katolicyzmu polskiego znalazło swój wyraz w szukaniu nowoczesnych form oddziaływania duszpasterskiego, ożywienia życia sakramentalnego i liturgii kościelnej, uaktywnieniu laikatu w odrodzonych bractwach kościelnych i III Zakonie. Ruch odrodzeniowy tworzono nie tylko na bazie intelektualno-doktrynalnej, lecz wskutek apostolskiego oddziaływania duchownych posiadających znaczny autorytet moralny. Zupełnie nowym aspektem tego oddziaływania było wyjście poza osobistą dewocję i skupienie uwagi na zagadnieniach społecznych. Nowa generacja kapucynów nie wahała się poruszać w swych wystąpieniach spraw społecznych, a także narodowych. Wierni tłumnie zbierali się w kościołach kapucyńskich na kazaniach, zwłaszcza wówczas, kiedy posiadały one podteksty patriotyczne. Tworzyły się przede wszystkim kręgi ludzi świeckich związanych z osobą kierownika duchowego, gorliwego duszpasterza, dobrego spowiednika i kaznodziei ${ }^{44}$. Kapucyni wypracowywali i uboga-

c z a k, Franciszkańskie początki Trzeciego Zakonu, „Studia Franciszkańskie” 6(1994), s. 225-236; Duchowość średniowiecza. Tekst i komentarz. Opracował ks. Józef W a r z e s z a k. Wydawnictwo Archidiecezji Warszawskiej, Warszawa 2001, s. 9.

${ }^{43}$ Por. L. B o r i e 11 o, Giovanna della C r o c e, B. S e c o n d i n, Historia duchowości. Duchowość chrześcijańska czasów współczesnych, t. 6, Kraków 1998, s. 15n.

${ }^{44}$ Por. A. B u d z i a r e k, Kapucyni w Lublinie. Dzieje klasztoru w latach 1721-1864, Warszawa-Lublin 1996, s. 144n; J. D u chni e w s k i, Przejawy zakonotwórczej aktywności kapucynów polskich w XIX wieku, „Roczniki Teologiczno-Kanoniczne” 22(1975), z. 4, s. 99-101; E. J a bł oń s k a, Polskie odrodzenie religijne $w$ XIX w., „Więź” 5(1960), s. 63-64. 
cali „efektami specjalnymi” scenariusze nabożeństw. Na nabożeństwo majowe, odprawiane początkowo w godzinach rannych, składała się msza św., śpiewana Litania do Najsłodszego Serca Maryi i lektura fragmentu książki o. Prokopa Leszczyńskiego ${ }^{45}$.

Teren Warszawy stał się największym ośrodkiem ruchu odnowy religijnej w Królestwie Polskim w drugiej połowie XIX wieku. Wśród ludności obserwowano wzmożone zapotrzebowanie na autentyczną, żarliwą religijność ${ }^{46}$, co znalazło odzwierciedlenie przede wszystkim w zaangażowaniu w powstających różnego rodzaju kołach, bractwach, stowarzyszeniach. Były to m.in. koła żywego różańca, Bractwo św. Wincentego á Paulo i szczególnie dynamicznie rozwijający się III Zakon św. Franciszka z Asyżu. W czasach zaborów taka forma zrzeszania ludzi w celu wspólnej modlitwy i działalności dobroczynnej wymykała się władzom zaborczym spod kontroli. Dawało to okazję nie tylko do rozbudzania religijności i pełnienia czynów miłosierdzia, ale podtrzymywało również ducha narodu ${ }^{47}$.

Grupy kapucynów realizowała program budzenia życia religijnego i narodowego XIX wieku w szerokich kręgach społeczeństwa polskiego. Intensyfikowali oni życie religijne $\mathrm{w}$ masowych i indywidualnych formach, inicjowali działalność wspólnot przyklasztornych o charakterze dewocyjno-społecznym. Poprzez ambonę a zwłaszcza konfesjonał pobudzali i odpowiednio formowali sumienia narodu. W połowie XIX wieku ambona i konfesjonał kapucyński w miejskich ośrodkach obsadzone były zdolnymi i żarliwymi zakonnikami ${ }^{48}$. O. Prokop w relacji bł. Honorata, gdziekolwiek się znalazł miał jedno nadprzyrodzone pragnienie związane z szerzeniem Królestwa Bożego. Podejmując pracę duszpasterską, czynił to $\mathrm{z}$ takim zaangażowaniem, że widoczne były owoce tej posługi. Rozbudzał, pod tchnieniem głoszonego słowa życie duchowe. Młodzież, która jest według Koźmińskiego

\footnotetext{
${ }^{45}$ Miesiąc Maryi dla ludu wiejskiego $i$ dla odprawiających to nabożeństwo $w$ gronie domowników ułożony, a na szczególna cześć Boga-Rodzicy ofiarowany przez x. Prokopa kapucyna, Warszawa 1853; por. R. P r e j s, Maryjne piśmiennictwo o. Prokopa Leszczyńskiego, kapucyna, „Studia Franciszkańskie” 3(1988), s. 333-348.

${ }^{46}$ Por. H. D yl ąg ow a, Od upadku państwa polskiego po powstanie listopadowe (1795-1831), [w:] Chrześcijaństwo w Polsce. Zarys przemian 966-1945, red. J. Kłoc z o w s k i, Towarzystwo Naukowe KUL, Lublin 1980, s. 226.

${ }^{47}$ Por. J. Kł o c z o w s k i, Dzieje chrześcijaństwa polskiego, Editions du Dialogue, Paryż 1991, s. 48.

${ }^{48}$ Por. M. B u d z i a r e k, Kapucyni w Lublinie, s. 184.
} 
wymagającym podmiotem pracy duszpasterskiej i, ,zwykle $\mathrm{z}$ góry traktuje wierzących jako zacofanych", widząc i słuchając człowieka „wszechstronnie wykształconego, imponującego im swoją wiedzą i wyjaśniającego wszystko racjonalnie $\mathrm{i}$ gruntownie, a przede wszystkim świetlanym przykładem swojego życia, zaczynała poważnie traktować życie religijne. W parafiach, w których głosił kazania budziła się pobożność i przystępowanie do sakramentów. Szczególnie owocnie przeżywane były misje prowadzone przez o. Leszczyńskiego. Tłumy ludzi w kościołach, konfesjonały oblężone, w których spowiadało po pięćdziesięciu kapłanów. Widok ten przypominał powrót wspaniałych czasów wiary i pobożności ${ }^{49}$. Darem kaznodziejskim porywał thumy i sfery inteligencji, język jego był podobny do ks. Skargi, krasomówstwo piękne przez swoją prostotę i szlachetność. Postać jego wyglądała majestatycznie, gdy zjawiał się na ambonie. Umieszczając duszpasterstwo kręgów arystokratycznych i ziemiańsko-inteligenckich pośród strategicznych obszarów swojej działalności, znakomicie wyczuwał formacyjny potencjał kazań i uczynił je ważnym elementem podjętej przez siebie długofalowej, zakrojonej na szeroką skalę kampanii społecznej ${ }^{50}$.

Poprzez ambonę i konfesjonał, tworzenie kręgów związanych $\mathrm{z}$ osobą spowiednika, udział $\mathrm{w}$ misjach oraz aktywizacja organizacji religijno-społecznych kapucyni kładli podwaliny pod XIX-wieczną rewolucję moralną społeczeństwa polskiego. Propagowany przez nich ruch odrodzenia religijnego prowadził w konsekwencji do ożywienia społecznego narodu dążącego do odzyskania suwerenności państwowej. Dzięki tak pojętemu oddziaływaniu duszpasterskiemu, kapucyni stali się jednym z głównych motorów odrodzenia religijnego i patriotycznego w Królestwie Polskim połowy XIX wieku ${ }^{51}$.

Ojciec Prokop odznaczał się zawsze gorącą miłością, synowską ufnością i serdecznym nabożeństwem do Przenajświętszej Maryi Panny.

\footnotetext{
${ }^{49}$ Por. H. Koźmińs ki, Ojciec Prokop Kapucyn, s. 32n.

${ }^{50}$ Por. A. K a p u ś c i ń s k a, ,Boska teoria socjalna, na której postęp ludzkości zawisł”. Prokop Leszczyński (1812-1895) i literacki projekt kordialno-ultramontański, Poznań 2015, s. 254.

${ }^{51}$ Por. M. B u d z i a r e k, Kapucyni w Lublinie, s. 184; M. B r z o z o w s k i, Działalność kaznodziejsko-misyjna kapucynów, [w:] Trzysta lat kapucynów w Polsce 16811981. Materiały z Sympozjum w Zakroczymiu 27-29 październik 1981, ZakroczymWarszawa-Kraków 1987, s. 227-234.
} 
Występował jako propagator pogłębionej duchowości maryjnej wśród wiernych obojga płci ze wszystkich środowisk społecznych ${ }^{52}$. Zainspirowany działalnością warszawskich bernardynów, erygował lubelską gałęź Bractwa Niepokalanego Serca Panny Maryi, a mając ogromne wpływy osobiste, a przy tym wielki miłośnik ubóstwa franciszkańskiego, cierpliwy, pełen miłości, wyrozumiałości, doskonały kaznodzieja, niestrudzony samarytanin przyciągał do kościoła kapucyńskiego tłumy ludzi. Kościół kapucynów stał się jednym z najpotężniejszych ośrodków religijnych i społeczno-patriotycznych na Lubelszczyźnie. Niezwykle mocno rozbudowane praktyki religijne Bractwa, mające na celu uwielbienie Najświętszego Serca Maryi, zmuszały kapucyńskiego protektora do stałej i na wysokim poziomie stojącej obsługi duszpasterskiej. Leszczyński dokładał starań, aby nabożeństwa te były regularnie odprawiane, dbał o wysoki poziom wygłaszanych kazań i właściwe kierownictwo duchowe w konfesjonale. Kaplica Niepokalanego Serca Panny Maryi przy kapucyńskim kościele stała się jednym z najważniejszych miejsc kultu maryjnego w Lublinie. W niej to o. Prokop głosił nauki zachęcające do ufności w opiekę Najświętszej Maryi Panny, tu kruszono serca zatwardziałych grzeszników, tu też nabożeństwa skupiały wierny lud, który modlił się o nawrócenie grzeszników, tu rosła chwała Boża i cześć Niepokalanego Serca Maryi ${ }^{53}$. W prostej i szlachetnej formie swego stylu, przedstawiał obraz idealnej natury Boskiej, budzący cześć i głęboką wiarę w skuteczność orędownictwa Matki Najświętszej, dając także przykład z życia Maryi, dla każdej niewiasty chrześcijańskiej, na jakimkolwiek stanowisku. Matka Boża to żywy symbol połączenia różnych stanów społecznych, punkt zjednoczenia ludzkości, wspólny ideał cnoty ${ }^{54}$. Bractwo przez wzorową pracę opiekunów ,wielce przyczyniło się do rozbudowania życia religijnego w mieście i okolicy" ${ }^{, 55}$.

\footnotetext{
${ }^{52}$ Por. H. K o ź m i ń s k i, Ojciec Prokop Kapucyn, s. 37; A. K a p u ś c i ń s k a, „Boska teoria socjalna, na której postęp ludzkości zawisł", s. 178.

${ }^{53}$ Por. M. B u d z i a r e k, Kapucyni w Lublinie, s. 149n; por. W. C z e c z o t t, Wspomnienia o ś.p. Ojcu Prokopie, kapucynie, „Rodzina Seraficka” 1912, t. 3, s. 256; F. J. D u c h n i e w s k i, Z dziejów polskiej Prowincji kapucynów (1810-1921), s. 48.

${ }^{54}$ Por. A. Ka puścińska, „Boska teoria socjalna, na której postęp ludzkości zawisł", s. 185.

${ }^{55}$ M. B u d z i a r e k, Bractwo Niepokalanego Serca Maryi przy kościele kapucynów w Lublinie (1856-1864), [w:] Kościól i społeczeństwo. Rewolucje - demokracje -
} 
Trzeba nadmienić, że kult maryjny w zakonie kapucyńskim był zawsze żywy. Nabożeństwa organizowane w liczne święta maryjne miały podniosłą oprawę, były starannie przygotowane, co oczywiście wpływało na liczny w nich udział wiernych. Dużą popularnością cieszyły się nowo wprowadzone nabożeństwa majowe, których wielkim propagatorem był również o. Prokop Leszczyński. On to właśnie opracował specjalny podręcznik dla wiernych uczestniczących w nabożeństwach popołudniowych odprawianych codziennie w miesiącu maju. Kapucynom przypisuje się rozszerzenie i spopularyzowanie na terenie Królestwa Kongresowego nabożeństwa majowego. Pojawiło się ono jako ewenement w warszawskim kościele księży misjonarzy w $1852 \mathrm{r}$. Ojcu Beniaminowi, związanemu przyjaźnią z misjonarzami, bardzo przypadło do gustu i już w 1853 r. zorganizował je w licznie uczęszczanym podówczas kościele kapucynów w Warszawie, a w 1854 r. we wszystkich kościołach klasztornych prowincji ${ }^{56}$.

Ojciec Beniamin 15 maja 1853 roku erygował kanonicznie w kościele kapucynów w Lądzie Bractwo Przenajświętszej Krwi. Organizacja ta miała nie tylko cel dewocyjny, ale też program społeczny: opiekę nad chorymi, starszymi i opuszczonymi, a w szeregach bractwa znaleźli się ludzie ze wszystkich ówczesnych warstw społecznych. W Bractwie dawało się zauważyć przewagę kobiet. Wielka czcicielka Krwi Przenajświętszej Gutakowska w obłożnej chorobie podarowała o. Beniaminowi relikwie z komży Kaspra del Bufalo (zm. 1837 r.), założyciela tegoż bractwa ${ }^{57}$.

\section{Ukryte życie zakonne}

Zanik życia zakonnego zarówno na ziemiach polskich znajdujących się pod trzema zaborami, jak i w krajach Europy Zachodniej wyzwalał jednocześnie tendencję przeciwną - do jego odrodzenia.

totalitaryzmy. Studia z dziejów XIX i XX wieku, Lublin 1993, s. 59-62; T e n że, Kapucyni $w$ Lublinie, s. 145-151; A. K a puś cińs ka, „Boska teoria socjalna, na której postęp ludzkości zawisł", s. 179; F. J. D u c h n i e w s k i, Z dziejów polskiej Prowincji kapucynów (1810-1921), s. 48.

56 Por. M. B u dzi are k, Kapucyni w Lublinie, s. 146; F. J. D u ch n i e w s ki, Z dziejów polskiej Prowincji kapucynów (1810-1921), s. 46.

57 Por. Ł. J a n c z a k, Szymański Beniamin, „Encyklopedia Kościelna”, t. XXVIII, Warszawa 1905, s. 118; F. J. D u c h n i e w s k i, Z dziejów polskiej Prowincji kapucynów (1810-1921), s. 48. 
Ruch tworzenia nowych wspólnot zakonnych przystosowanych celami i typem działalności do nowej sytuacji społeczno-religijnej drugiej połowy XIX wieku był elementem składowym ogólnopolskiego ożywienia religijnego we wszystkich trzech zaborach. $\mathrm{Na}$ ziemiach polskich pod zaborem pruskim i austriackim powstawały zgromadzenia naśladujące życie dawnych zakonów pod względem wspólnego zamieszkania w klasztorze i noszenia jednakowego stroju zakonnego. Członkinie nowych zgromadzeń zakonnych nie zachowywały ścisłej klauzury. Nowe zapotrzebowania społeczne oraz aspiracje znacznej większości narodu polskiego bezpośrednio wpływały na ogromne rozbudowanie inicjatyw zakonotwórczych - tak w kraju, jak i na emigracji. Poza granicami państw zaborczych inicjatywy te skupiały się wokół zmartwychwstańców, zaś w Królestwie Polskim ośrodkiem tym stali się kapucyni. Oni stanowili najaktywniejszą grupę inicjatorów i kierowników duchowych nowych kongregacji zakonnych. Wśród niewiast, które szukały u nich przewodnictwa duchowego w różnych momentach swego życia, były późniejsze założycielki dziewiętnastowiecznych zgromadzeń habitowych i niehabitowych ${ }^{58}$.

Tym co istotne w duchowości jest uległość Duchowi Świętemu, rozumiana jako otwarcie na Jego działanie i posłuszeństwo wiary. W Katechizmie zakonnym Błogosławiony objaśnia, że należy wstąpić do zakonu, do którego Duch Święty pociąga. Duchowość to przede wszystkim życie pełne uległości Duchowi Świętemu. Można ten pociąg poznać z usposobienia wewnętrznego. Uległość Duchowi Świętemu domaga się przyjęcia darów męstwa i umiejętności rozróżniania. Pociąg do życia kontemplacyjnego, do samotności, do modlitwy jest wskazówką powołania do zakonu kontemplacyjnego, gorliwość o zbawienie dusz - do zakonu czynnego, natomiast pragnienie umartwień i pokuty - do zakonu o surowej regule. Duch Święty, który rządzi Kościołem, pobudza dusze wybrane do walczenia z zepsuciem czasu i wykorzenienia szerzących się występków.

\footnotetext{
${ }^{58}$ Por. B. S z e w c z u 1, Działalność zakonodawcza błogosławionego Honorata Koźmińskiego a nowe instytuty $w$ Kościele katolickim, s. 62; E. J a b łoń s k a, Polskie odrodzenie religijne $w$ XIX w., s. 57-68; A. B u dzi a re k, Kapucyni $w$ Lublinie, s. 152; M. H. M a z u r e k, Powstanie i rozwój ukrytych zgromadzeń, s. 53n; J. R ył, Zakonodawcza działalność Honorata Koźmińskiego OFMCap w Polsce pod zaborem rosyjskim, „Studia Franciszkańskie” 2(1986), s. 257; H. K o s y r a - C i e ś 1 a k, R. S z y m c zak, Poszłam siać do Polski $i$ wzeszło. 150 lat pracy Zgromadzenia Sióstr Niepokalanek, t. 1, Siostry Niepokalanki, Szymanów 2004, s. 10.
} 
Przynagla do oddawania się ćwiczeniom wyższej pobożności i poświęcenia się uczynkom miłości. On jest sprawcą wzrostu jawnych zgromadzeń zakonnych w tym opłakanym XIX wieku, jak też tych, które prowadzą życie ukryte przed światem. Zgromadzenia habitowe, których członkowie mieszkają wspólnie w klasztorach, miały zamkniętą drogę do zakładania domów na ziemiach polskich pod zaborem rosyjskim. Dlatego musiano zrezygnować z dwóch istotnych elementów życia zakonnego - wspólnego mieszkania w klasztorze i noszenia habitu, aby upodobnić się zewnętrznie do wiernych świeckich. Dopiero na wzór Chrystusa i Maryi całkowite ukrycie konsekracji Bogu pozwalało na podejmowanie pracy dla dobra Kościoła i bliźnich ${ }^{59}$.

Błogosławiony Honorat rozumiał, że w zaistniałych warunkach politycznych są tylko dwie możliwości: rezygnacja z życia zakonnego i dążenia do doskonałości chrześcijańskiej albo naśladowanie Jezusa Chrystusa w ukryciu, aby uniknąć prześladowania. Pierwsza nie była dla niego do zaakceptowania, uważał bowiem, że życie zakonne pochodzi z nauczania i przykładu Chrystusa, więc ustać nie może, oraz zawsze i wszędzie jest potrzebne Kościołowi, bo bez niego nie byłaby głoszona Ewangelia. Był pewien, że forma ukrytego życia zakonnego jest jedyną i najodpowiedniejszą dla Kościoła XIX wieku. Sam Założyciel Kościoła wiódł życie ukryte przed światem, nie był znany prawie nikomu ze swego boskiego posłannictwa, pochodzenia i poświęcenia się Bogu i sprawie zbawienia ${ }^{60}$. Jak więc widać, o. Honorat niezależnie od sytuacji politycznej wzór i początek życia ukrytego dostrzegał w Ewangelii, a dokładniej w naśladowaniu życia ukrytego samego Chrystusa, który przez 30 lat nie był znany nikomu jako Syn Boży posłany w celu zbawienia świata. Zbawiciel nauczał, aby kryć się z uczynkami pobożności: z modlitwą, umartwieniem i miłosierdziem (...). Daleko bardziej chwalebną musi być rzeczą, krycie się przed światem ze swoim całkowitym oddaniem się Bogu i dążeniem do doskonałości chrześcijańskiej

\footnotetext{
${ }^{59}$ Por. H. K o ź m i ń s k i, O Zgromadzeniach ukrytych przed światem, s. 12; T e n ż e, Katechizm zakonny, s. 82; B. S z e w c z u 1, Działalność zakonodawcza błogosławionego Honorata Koźmińskiego a nowe instytuty w Kościele katolickim, s. 64; K. S y n o w c z y k, Obecność ukryta na podstawie pism bt. Honorata Koźmińskiego, s. 37n; por. M. C h mi e l e w s k i, Duchowość wedtug Jana Pawła II, s. 70.

${ }^{60} \mathrm{H}$. Koźmiński, O zgromadzeniach ukrytych przed światem, s. 2. 83; por. B. S z e w c z u 1, Działalność zakonodawcza błogosławionego Honorata Koźmińskiego a nowe instytuty w Kościele katolickim, s. 71. 257.
} 
i poświęceniem dla sprawy zbawienia dusz, choćby nie groziło żadne niebezpieczeństwo. Stąd o. Honorat zachęcał członków swych zgromadzeń, aby pozostali w ukryciu także wtedy, gdy po odzyskaniu niepodległości zmienią się okoliczności i życie zakonne będzie można prowadzić w sposób jawny jak dawniej ${ }^{61}$.

Rezygnacja $\mathrm{z}$ noszenia habitu $\mathrm{w}$ nowych zgromadzeniach honorackich sprawiła, że życie ich członków stało się niezauważalne, czyli niedostrzegalne dla otoczenia. Nowe osoby zakonne jawiły się w społeczeństwie jako wzorowi katolicy i katoliczki. Stąd o. Honorat zgromadzenia bezhabitowe określał mianem ukrytych, a ten rodzaj życia zakonnego nazywał życiem ukrytym przed światem, czyli dążeniem do osiągnięcia doskonałości chrześcijańskiej bez żadnych oznak zewnętrznych. Ukrycie według o. Honorata to jakby najważniejsze „słowo” - sposób, którym Bóg wypowiedział swoją miłość do człowieka. Co więcej, uważa iż jest to największy przymiot Bożej miłości. Swoje twierdzenie uzasadnia w ten sposób: „Rzeczywiście, jest to przymiotem miłości, że im jest prawdziwszą i szlachetniejszą, tym bardziej pożąda ukrycia, mało o sobie mówi, ale dużo czyni; nie szuka wdzięczności, ale okazji do poświęceń; nie chce być znaną, ani zapłaconą, bo ma nagrodę w samym świadczeniu dobra tym, których miłuje. Najszczęśliwsza jest wtedy, gdy może uszczęśliwiać umiłowane przez siebie istoty, czyniąc im dobrze w ukryciu" ${ }^{\prime 2}$.

Błogosławiony był mocno przekonany, że życie zakonne jest instytucją Boską i ustać nie może, bo bez niego nie mogła by być wypełniona Ewangelia Święta, dlatego Duch Święty nie przestaje budzić powołań do tego życia nawet w czasie prześladowania; gdy więc dusze tak powołane nie mogą mieć sposobności poświęcania się jawnie Bogu, dla braku klasztorów, muszą obmyślać sposoby służenia Bogu skrycie.

${ }^{61}$ H. K o ź m i ń s k i, O zgromadzeniach ukrytych przed światem, s. 3. 79-80; T e n że, Listy okólne do zgromadzeń ukrytych, [w:] Pisma, t. 12, Warszawa 1998, L. 36, s. 229; por. E. K r ę żl i k, Identità e principali impegni della ,vita religiosa naskosta” nel pensiero di P. Onorata Koźmiński, Roma 1997, s. 47-71; B. S z e w c z u 1, Działalność zakonodawcza blogosławionego Honorata Koźmińskiego a nowe instytuty w Kościele katolickim, s. 259n.

${ }^{62}$ Brat Honorat [K o źm i ń s k i], Powieść nad powieściami, t. 1, Historia miłości Bożej względem rodu ludzkiego, Włocławek 1909, s. 362-363; T e n ż e, O zgromadzeniach ukrytych przed światem, s. 79; T e n że, Odpowiedź na ankietę „Przeglądu Powszechnego", s. 33; por. B. S z e w c z u 1, Działalność zakonodawcza błogosławionego Honorata Koźmińskiego a nowe instytuty w Kościele katolickim, s. 258. 
Realizując Boży zamiar Honorat pragnął, aby przez tę nową formę życia zakonnego, jaką zainicjował, szerzyła się chwała Boża. Osoby, które Bóg powoływał do takiej służby, pozostawałyby wśród świata, by były dobrym zaczynem i przyczyniały się do szerzenia królestwa Bożego na ziemi. W tym czasie wielu Polaków pragnących poświęcić swe życie Bogu zastanawiało się nad wyjazdem za granicę, by tam, w istniejących zakonach, prowadzić życie oddane całkowicie Bogu. Takie rozwiązanie pociągało za sobą pozbawienie kraju i Kościoła osób wartościowych, świętych i rozmodlonych, a także obdarzonych powołaniem. Stąd zamysł umożliwienia realizacji powołania zakonnego w kraju, w trudnych okolicznościach czasu i miejsca. Honoratowi chodziło o autentyczne, ale ukryte przed światem poświęcenie się Bogu ${ }^{63}$. Przez życie ukryte przed światem rozumie się zwykle dążenie do doskonałości chrześcijańskiej bez żadnych oznak zewnętrznych ${ }^{64}$.

Ojciec Honorat osobom zakonnym praktykującym życie ukryte mówi jasno o dążeniu do świętości jako obowiązku wynikającym z powołania. Podkreśla, że nie wystarczy realizowanie świętości zewnętrznej, ani też nie jest konieczny tytuł świętości przyznany przez Kościół w sposób uroczysty. W tym powołaniu potrzebna jest przede wszystkim realizacja świętości wewnętrznej. Ona to uzdalnia osoby zakonne do pomnażania „w swoim wnętrzu” życia Bożego. Wzrost duchowy z kolei przygotowuje je do zjednoczenia z Bogiem. Praktyka tego sposobu życia ze świadomością przybliżania się sercem do Zbawiciela, wpatrywanie się w Niego od Wcielenia do śmierci i zmartwychwstania powinno mobilizować osoby zakonne do zdobywania na ziemi doskonałości, która zaowocuje radością w niebie ${ }^{65}$.

Jednak szczególnym źródłem poznania życia Chrystusa, uprzywilejowanym środkiem usłyszenia zbawczego orędzia i pewną drogą do osobistej świętości była dla Błogosławionego Ewangelia. Ona podaje

${ }^{63}$ Por. H. Ko źmińs ki, O zgromadzeniach ukrytych przed światem, s. 6n; por. B. S z e w c z u 1, Działalność zakonodawcza błogostawionego Honorata Koźmińskiego a nowe instytuty w Kościele katolickim, s. 70; D. W i e 1 g u t, Błogosławionego Honorata Koźmińskiego teologia ukrytego życia zakonnego, [w:] W kręgu dziejów Kościoła i rodziny franciszkańskiej, red. R. P r e j s OFMCap, Drukarnia Diecezjalna Sandomierz, Warszawa 1999, s. 321.

${ }^{64} \mathrm{H}$. K o ź m iń s k i, O zgromadzeniach ukrytych przed światem, s. 1; B. S z e w c z u 1, Działalność zakonodawcza błogosławionego Honorata Koźmińskiego a nowe instytuty w Kościele katolickim, s. 258.

${ }^{65}$ Por. H. K o ź m i ń s k i, Katechizm zakonny, s. 30. 
nam słowa i opisuje czyny Jezusa, a zarazem określa sposób życia chrześcijańskiego i zakonnego. W Ewangelii miłość Boga ukryta jest w Jego słowie, jakie kieruje On do człowieka i pragnie, by je usłyszał, zrozumiał, przyjął i zachował. Dał temu wyraz w słowach: „Owa tajemnica najwyższej miłości zawsze jest Ewangelią, czyli dobrą nowiną, i słusznie Pismo Święte nazywa ją tajemnicą ukrytą przed wiekami, tj. zostającą zawsze $\mathrm{w}$ niejakim półcieniu. Jest nią już przez to samo, że jest najgłębszą $\mathrm{z}$ tajemnic Bożych, a raczej całkiem niezgłębioną i przez wszystkie wieki zgłębić się zupełnie nie dającą. Ale zdaje się, że Pan Bóg z umysłu zawsze ją w ukryciu utrzymuje, zapewne zostawiając lepsze jej wyjaśnienie na czas w Opatrzności swojej zamierzony"

Życie poświęcone Bogu w ukryciu przed światem jest większą ofiarą i więcej sprzyja utrzymaniu ducha zaparcia i umartwienia wewnętrznego. Natomiast zniecierpliwienie, ciągłe doszukiwanie się własnych racji, poczucie niezrozumienia i skrzywdzenia oraz nieustanne narzekanie i szemranie, nie mają nic wspólnego $\mathrm{z}$ duchowością ukrycia $\mathrm{i}$ istotą konsekracji zakonnej $^{67}$. W zgromadzeniach niehabitowych nie zmienia się sama istota konsekracji, lecz tylko jego forma, której racje pozostają raczej historyczne, chociaż można podać również jej uzasadnienie teologiczne. Konsekracja taka nie manifestuje się w żaden formalny sposób wobec ludzi: strój, który jest widocznym znakiem przynależności do zakonu habitowego, nie wyróżnia osób, które wybrały życie w zgromadzeniach ukrytych. Dążenie do doskonałości ma odbywać się nie poza zakonem, lecz w nim samym, jednakże ,ukrytym” przed światem. To ukrycie pojmuje o. Honorat jako złożenie Bogu z siebie ofiary w taki sposób, by nikt nie mógł się o niej dowiedzieć. Ukrycie konsekracji jest pewnego rodzaju ogołoceniem: oto wszystkie przywileje, które zwyczajowo i kulturowo są udziałem księży, zakonników i sióstr habitowych, jak choćby szacunek społeczny czy sympatia środowiska społecznego, omijają tych, którzy żyją w ukryciu, a fakt ich konsekracji jest znany jedynie wspólnocie i Bogu. W konsekwencji o. Honorat określa powołanie do tej formy życia mianem „łaski nad łaskami”, która powinna być szczególną tajemnicą między człowiekiem a Bogiem.

\footnotetext{
${ }^{66}$ H. K o ź m i ń s k i, Powieść nad powieściami, t. II, Włocławek 1910, s. 143; K. S y n o w c z y k, Obecność ukryta na podstawie pism bł. Honorata Koźmińskiego, s. 32.

${ }^{67} \mathrm{H}$. K o ź m iń s k i, O zgromadzeniach ukrytych przed światem, s. 5; K. S y n o w c z y k, Obecność ukryta na podstawie pism bł. Honorata Koźmińskiego, s. 78.
} 
Powodem podjęcia życia ukrytego nie może być lęk przed trudnościami w świecie, szukanie łatwiejszej drogi czy też zwykła ucieczka, ale szukanie chwały Bożej i troska o zbawienie ludzi ${ }^{68}$.

Poszczególne zgromadzenia niehabitowe miały - według zamiaru o. Honorata z Białej - poświęcić się czynnej praktyce miłosierdzia względem określonej grupy społecznej lub zawodowej. Doświadczenie ze skierowaniem do działalności charytatywnej tercjarek, a następnie zaangażowanie w praktykę miłosierdzia felicjanek, trwające do chwili rozwiązania ich przez władze carskie po powstaniu styczniowym, dla o. Koźmińskiego stało się okazją do wyznaczenia pól praktyki miłosierdzia zgromadzeniom niehabitowym ${ }^{69}$. W przyjmowaniu do zgromadzeń ukrytych o. Honorat wymagał przede wszystkim dobrej intencji, nabywania cnót i całkowitego oddania się Bogu. Nabywać ducha serafickiego, to nabywać cnoty, którymi jaśniał św. Franciszek. Są to przede wszystkim: pokora, pokuta, ubóstwo, miłość Boga i bliźniego. Wstąpienie na drogę rad ewangelicznych nie uwalniało bynajmniej od pracy nad utrzymaniem, nie wiązało się z wygodnym stylem czy zabezpieczeniem na przyszłość i starość. Życie w tych zgromadzeniach wymagało stawania się bezinteresowną, pełną miłości ofiarą dla Boga ${ }^{70}$. Duch serafickiej miłości, czyli szaleńcza miłość Boga, musi się bowiem przekładać na miłość człowieka, żywą świątynię Bożą, przejmując się szczególnie jego duchową biedą, będąc dalekim od gniewu, który niszczy więzy międzyludzkie, przemieniając się na służbę wobec braci i sióstr, oddając za nich życie. Wola naśladowcy św. Franciszka powinna kształtować pragnienie spotkania $\mathrm{z}$ drugim człowiekiem ${ }^{71}$.

${ }^{68}$ Zob. H. Koźmińs ki, O zgromadzeniach ukrytych przed światem, s. 3; por. K. S y n o w c z y k, Obecność ukryta na podstawie pism bł. Honorata Koźmińskiego, s. 52n; M. S z y m u l a, Duchowość zakonna, s. 124.

${ }^{69}$ Por. J. R. B a r, Zgromadzenie Sióstr Serafitek 1881-1961, „Prawo Kanoniczne” 6(1963), s. 75-211.

${ }^{70}$ Por. H. K o ź m iń s k i, Wiadomości o zgromadzeniach prowadzacych życie ukryte przed światem, s. 13; tenże, Nauki o Trzecim Zakonie Ś.O. Franciszka, s. 73; por. J. B a n a s i u k, Franciszkanin świecki na drodze do świętości wedtug bł. Honorata, [w:] W szkole świętości błogosławionego Honorata, red. Tomasz P ł o n k a OFMCap, Sandomierz-Zakroczym 2008, s. 292; M. H. M a z u r e k, Powstanie i rozwój ukrytych zgromadzeń bł. Honorata Koźmińskiego w latach 1874-1908, s. 124.

${ }^{71}$ Por. H. K o źm iń s k i, Nauki o Trzecim Zakonie Ś.O. Franciszka, s. 75; J. B a $\mathrm{n}$ a s i u k, Franciszkanin świecki na drodze do świętości wedtug bl. Honorata, s. 294; K. S y n o w c z y k, Błogostawieni studzy, s. 97. 


\section{Zakończenie}

Duchowość życia ukrytego to przede wszystkim styl życia i sposób dążenia do doskonałości chrześcijańskiej bez żadnych oznak zewnętrznych. Członkowie zgromadzeń zdążają do świętości, oddają chwałę Bogu i przyczyniają się do zbawienia bliźnich. Ukrycie w zamyśle o. Honorata to metodę trafiania osoby konsekrowanej do człowieka we współczesnym mu świecie, podkreślająca ważność świadectwa samej obecności, bez wykonywania wielkich czynów i bez ujawniania swego powołania zakonnego. Szerzenie chwały Bożej i dążenie do własnej świętości wymaga złożenia z siebie większej ofiary Bogu przez naśladowanie życia ukrytego Chrystusa. Ukrycie kształtuje życie duchowe członków zgromadzeń honorackich i w połączeniu z cichością i pracowitością jest największą ozdobą ich duchowości. Ciche apostolstwo domowe, przykład własnego życia i słowa, służy utrzymaniu wiary, rozbudzaniu pobożności i przywróceniu gorliwości pierwszych wieków Kościoła. Ubogacone duchem św. Franciszka w kapucyńskim wykonaniu zachęca do serafickiego zapału w apostołowaniu i żarliwej miłości Boga i bliźniego.

\section{Bibliografia}

Banasiuk J., Franciszkanin świecki na drodze do świętości wedtug bt. Honorata, [w:] W szkole świętości błogostawionego Honorata, red. Tomasz Płonka OFMCap, Sandomierz-Zakroczym 2008, s. 289-309.

Bar R. J., Zgromadzenie Sióstr Serafitek 1881-1961, „Prawo Kanoniczne” 6(1963), s. 75-211.

Bar R. J., Tercjarstwo franciszkańskie, Kraków 1945.

Bender R., Rewolucja moralna 1861 r., „Zeszyty Naukowe KUL” 4(1961), nr 3, s. 83-94.

Boriello L., Giovanna della Croce, Secondin B., Historia duchowości. Duchowość chrześcijańska czasów współczesnych, t. 6, Kraków 1998.

Brzozowski M., Działalność kaznodziejsko-misyjna kapucynów, [w:] Trzysta lat kapucynów w Polsce 1681-1981. Materiały z Sympozjum w Zakroczymiu 2729 październik 1981, Zakroczym-Warszawa-Kraków 1987, s. 227-234.

Budziarek M., Kapucyni w Lublinie. Dzieje klasztoru w latach 1721-1864, Warszawa -Lublin 1996. 
Budziarek M., Bractwo Niepokalanego Serca Maryi przy kościele kapucynów w Lublinie (1856-1864), [w:] Kościót i społeczeństwo: rewolucje demokracje - totalitaryzmy. Studia z dziejów XIX i XX wieku, pod red. J. Walkusza, Lublin 1993, s. 59-67.

Chmielewski M., Duchowość wedtug Jana Pawta II. Studium na podstawie encyklik $i$ adhortacji, Lublin 2013.

Chmielewski M., Metodologia duchowości katolickiej, [w:] Teologia duchowości katolickiej, red. W. Słomka, M. Chmielewski i inni, Redakcja Wydawnictw Katolickiego Uniwersytetu Lubelskiego, Lublin 1993, s. 49-69.

Chmielewski M., Metodologiczne problemy posoborowej teologii duchowości katolickiej, Lublin 1999.

Ciardi F., Koinonia. Itinerario teologico-spirituale della comunità religiosa, Roma 1992.

Czeczott W., Wspomnienia o ś.p. Ojcu Prokopie, kapucynie, „Rodzina Seraficka" 1912, t. 3.

Dmowska B., Matka Maria Angela Truszkowska Założyciela Zgromadzenia Sióstr Felicjanek (1825-1899), t. 1. Życiorys, Buffalo N.Y., 1949.

Duchowość średniowiecza. Tekst i komentarz. Opracował ks. Józef Warzeszak, Warszawa 2001.

Duchniewski J. F., Z dziejów polskiej Prowincji kapucynów (1810-1921), [w:] $W$ stużbie pokoju i dobra. Jubileusz pięćdziesięciolecia odrodzenia Warszawskiej Prowincji Kapucynów. Księga Pamiątkowa, pr. zbr. pod red. R. Prejs, Warszawa 2002, s. s. 25-67.

Duchniewski F., Polska Prowincja Kapucynów w XIX wieku (1795-1864), [w:] Zakony franciszkańskie w Polsce, pod red J. Kłoczowskiego, t. 4, cz. 1, Lublin 1987, s. 5-209.

Duchniewski J., Przejawy zakonotwórczej aktywności kapucynów polskich w XIX wieku, ,Roczniki Teologiczno-Kanoniczne” 22(1975), z. 4, s. 99-107.

Dylągowa H., Od upadku państwa polskiego po powstanie listopadowe (1795-1831), [w:] Chrześcijaństwo w Polsce. Zarys przemian 966-1945, red. J. Kłoczowski, Towarzystwo Naukowe KUL, Lublin 1980, s. 203-218.

Tekst Dziennik Praw Królestwa Polskiego, t. 62,1864, 192, s. 420-447.

Encyklika „Auspicato” papieża Leona XIII, [w:] Św. Franciszek z Asyżu i jego Trzeci Zakon (dokumenty ostatnich papieży), red. i tłum. J. Bar, Z. Włodarczyk, Wrocław-Kraków 1948.

Filek O., Wokół terminu ,duchowośc”, ,Roczniki Teologiczno-Kanoniczne” 3(1966), s. 41-52.

Gach P.P., Kasaty zakonów na ziemiach dawnej Rzeczpospolitej i Śląska 1773-1914, Lublin 1984.

Gajewski S., Kasata klasztorów w diecezji lubelskiej w roku 1864, „Roczniki Humanistyczne" 21(1972), nr 1-2, s. 351-390. 
Grzybowski M. M., Postawa Wincentego Chościak-Popiela, biskupa płockiego, wobec kasaty klasztorów z 1864 r. w jego diecezji, „Studia Płockie” 11(1983), s. 257-272.

Il Terzo Ordine Francescano. Riflessioni di storia e di spiritualità, Roma 1970.

Iriarte L., Historia franciszkanizmu, Kraków 1998.

Jabłońska-Deptuła E., Przystosowanie i opór. Zakony męskie w Królestwie Kongresowym, Instytut Wydawniczy PAX, Warszawa 1983.

Jabłońska-Deptuła E., Gawrysiakowa J., Z zagadnień religijno-społecznego ruchu kobiet w Królestwie Polskim połowy XIX wieku, „Roczniki Humanistyczne" 18(1970), z. 2, s. 101-139.

Jabłońska-Deptuła E., Polskie odrodzenie religijne w XIX wieku, „Więź” 3(1960), nr 5, s. 53-70.

Jakubczyk A., Zgromadzenie Stug Jezusa w społeczeństwie polskim w latach 1884-1939, Warszawa 2001.

Janczak Ł., Szymański Beniamin, „Encyklopedia Kościelna”, t. XXVIII, Warszawa 1905, s. 116-124.

Kaczyńska E., Ludzie ukarani. Więzienia i system kar w Królestwie Polskim 1815-1914, Warszawa 1989.

Kapuścińska A., „Boska teoria socjalna, na której postęp ludzkości zawisł”. Prokop Leszczyński (1812-1895) i literacki projekt kordialno-ultramontański, Poznań 2015.

Kieniewicz S., Historia Polski (1795-1918), Warszawa 1968.

Kłoczowski J., Dzieje chrześcijaństwa polskiego, Paryż 1991.

Koska D., Życie ukryte przed światem. Dzieje klarysek kapucynek z Przasnysza - 150 lat istnienia zakonu, Pelplin 2017.

Kosyra-Cieślak H., Szymczak R., Poszłam siać do Polski $i$ wzeszło. 150 lat pracy Zgromadzenia Sióstr Niepokalanek, t. 1, Siostry Niepokalanki, Szymanów 2004.

Koźmiński H., Listy okólne do zgromadzeń ukrytych 1884-1914, (Pisma, t. 12), opr. H. I. Szumił, Warszawa 1998.

Koźmiński H., Listy do przełożonych $i$ współbraci Zakonu Braci Mniejszych Kapucynów 1867-1916, (Pisma, t. 2), opr. H. I. Szumił, Warszawa 1997.

Koźmiński, Wiadomości o zgromadzeniach prowadzacych życie ukryte przed światem, [w:] Wybór pism o. Honorata Koźmińskiego, cz. 5, Polskie teksty ascetyczne, t. XI, cz. 5, Warszawa 1988, s. 9-78.

Koźmiński H., Nauki o Trzecim Zakonie Ś.O. Franciszka, Warszawa 1920.

Koźmiński H., Święty Franciszek Seraficki jego życie, wielkie dzieła, duch, pisma i nauki i ich odbicie w naśladowcach Jego, t. 4, Warszawa 1913.

[Koźmiński] H., Powieść nad powieściami, Historia miłości Bożej względem rodu ludzkiego, t. I, Włocławek 1909; t. II, Włocławek 1910.

Koźmiński H., Odpowiedź na ankietę „Przegladu Powszechnego”: Jakie sa szczególniejsze zadania, które katolicyzm u nas w Polsce ma dzisiaj do spetnienia?, „Przegląd Powszechny” 5(1906), s. 18-74. 
Koźmiński H., O zgromadzeniach ukrytych przed światem, Kraków [1901]. Koźmiński H., Katechizm zakonny, II C, 33, bd, (mps), [w:] Biblioteka Warszawskiej Prowincji Kapucynów w Zakroczymiu.

Koźmiński H., Ojciec Prokop Kapucyn, Warszawa 1895.

Koźmiński H., Wiadomości o nowych zgromadzeniach zakonnych powstałych w tym wieku w różnych krajach katolickich. Ttumaczenie z francuskiego, Kraków 1890.

Krężlik E., Identità e principali impegni della „vita religiosa naskosta” nel pensiero di P. Onorata Koźmiński, Roma 1997.

Langkammer H., Duch Święty a duchowość, Wrocław 1999.

Langhammer H., Biblijne podstawy duchowości chrześcijańskiej, Wrocław 1987.

Lemańska K., Fenomen ukrytego życia zakonnego na przyktadzie zgromadzeń założonych przez o. Honorata Koźmińskiego, Lublin 1995.

Marecki J., Prejs R., Zarys historii kapucynów w Polsce, Kraków 2004.

Mazurek H. M, Powstanie i rozwój ukrytych zgromadzeń bt. Honorata Koźmińskiego w latach 1874-1908, Opracowała i przygotowała do druku Halina Irena Szumił, Sandomierz 2009.

Miesiac Maryi dla ludu wiejskiego $i$ dla odprawiajacych to nabożeństwo w gronie domowników ułożony, a na szczególna cześć Boga-Rodzicy ofiarowany przez x. Prokopa kapucyna, Warszawa 1853.

Niebelski E., Duchowieństwo lubelskie i podlaskie w powstaniu 1863 roku i na zestaniu w Rosji, Lublin 2002.

Nowak J. A., Duchowość osób konsekrowanych, [w:] Vita consecrata. Adhortacja. Tekst i komentarz, red. A. J. Nowak, Lublin 1998, s. 179-189.

O. Honorat, Miesiąc seraficzny: Miesiąc październik na cześć Ś. Franciszka, IIC, t. 31 (msp), [w:] Biblioteka Warszawskiej Prowincji Kapucynów w Zakroczymiu.

Pańczak M. A, Franciszkańskie początki Trzeciego Zakonu, „Studia Franciszkańskie" 6(1994), s. 225-236.

Pazzelli R., San Fracesco e il Terz Ordine, Padova 1982.

Piotrowski W., Wybór kazań niedzielnych, światecznych i przygodnych, t 1-4, Warszawa 1840.

Piotrowski W., Kazania w osobliwszych materiach, R 731, (rkp), [w:] Biblioteka Warszawskiej Prowincji Kapucynów w Zakroczymiu.

Piotrowski W., Przemówienia zakonne (1813-1835), t. 1 - 3, R 772/1; R 772/2; R 772/3 (rkp), [w:] Biblioteka Warszawskiej Prowincji Kapucynów w Zakroczymiu.

Prejs R., Kapucyni Prowincji Polskiej $w$ rewolucji moralnej $i$ powstaniu styczniowym, [w:] Życie zakonne w Królestwie Polskim w latach 1832-1864, red. W. Graczyk, J. M. Marszalska, Kraków 2015, s. 119-138.

Prejs P., Kapucyni Prowincji Polskiej po kasacie 1864 r. Losy-postawy, „Studia Franciszkańskie” 8(1997), s. 283-345. 
Prejs R., Zakonnicy franciszkańscy Królestwa Polskiego po kasacie 1864 r. Dzieje-postawy, Warszawa 2003.

Prejs R., Maryjne piśmiennictwo o. Prokopa Leszczyńskiego, kapucyna, „Studia Franciszkańskie” 3(1988), s. 333-348.

Rivi P., Francesco D 'Assisi e il laicato del suo tempo. Le origini dell 'Ordine Francescano Secolare, Padova 1989.

Rył J., Zakonodawcza działalność Honorata Koźmińskiego OFMCap w Polsce pod zaborem rosyjskim, „Studia Franciszkańskie” 2(1986), s. 257-264.

Słomka W., Teologia duchowości, [w:] M. Chmielewski, W. Słomka, Polscy teologowie duchowości, Lublin 1993, s. 231-241.

Synowczyk K., Obecność ukryta na podstawie pism bt. Honorata Koźmińskiego, Kalwaria Zebrzydowska 2012.

Synowczyk K., Błogosławieni studzy. Wokół Napomnień św. Franciszka z Asyżu, Kraków 2009.

Szewczul B., Działalność zakonodawcza błogosławionego Honorata Koźmińskiego a nowe instytuty $w$ Kościele katolickim. Studium prawno-historyczne, Warszawa 2008.

Szymula M., Duchowość zakonna wedtug pism bł. Honorata Koźmińskiego, Warszawa 1999.

Tarnawski P., La direzzione spirituale nelle vita consecrata femminile secondo il beato Onorata Koźmiński, Roma 2007.

Urbański S., Mistyczne perspektywy rozwoju duchowego chrześcijanina wskazane przez Jana Pawła II na poczatku trzeciego tysiaclecia, [w:] Duchowość na progu trzeciego tysiąclecia, red. M. Chmielewski, Lublin 1999, s. 101-112.

Werbiński I., Jedność i wielość duchowości, [w:] Teologia duchowości katolickiej, red. W. Słomka, M. Chmielewski i inni, Redakcja Wydawnictw Katolickiego Uniwersytetu Lubelskiego, Lublin 1993, s. 70-84.

Werner M., O. Honorat Koźmiński. Kapucyn 1829-1916, Poznań-Warszawa 1972.

Wiech S., Kasata klasztorów w Królestwie Polskim w 1864 r. w świetle wspomnień i relacji Dmitrija Anuczina, [w:] Życie zakonne w Królestwie Polskim w latach 1832-1864, red. W. Graczyk, J. M. Marszalska, Kraków 2015, s. 9-36.

Wielgut D., Błogostawionego Honorata Koźmińskiego teologia ukrytego życia zakonnego, [w:] $W$ kręgu dziejów Kościoła i rodziny franciszkańskiej, red. R. Prejs OFMCap, Drukarnia Diecezjalna Sandomierz, Warszawa 1999, s. 321-334.

Zieliński Z., Papiestwo i papieże dwóch ostatnich wieków, Warszawa 1999.

Żynel A., Duchowość chrześcijańska i jej podstawy w świetle teologii posoborowej, [w:] Chrześcijańska duchowość (seria „W nurcie zagadnień posoborowych", t. 14), red. B. Bejze, Warszawa 1981, s. 7-23. 


\title{
ANDRZEJ BARAN OFMCap
}

\section{UWARUNKOWANIA DUCHOWOŚCI ZGROMADZEŃ ZAKONNYCH ŻYCIA UKRYTEGO W KRÓLESTWIE POLSKIM W XIX WIEKU}

\begin{abstract}
Streszczenie: Przedmiotem analizy jest animacja kobiet w ramach duszpasterstwa prowadzonego przez kapucynów w okresie między powstaniem listopadowym i styczniowym. Oddziaływanie ukazane jest przez pryzmat wydarzeń społecznopolitycznych. Tło wywodu stanowi różnorodność form zaangażowania kobiet w okresie międzypowstaniowym. Artykuł łączy ogólną perspektywę wydarzeń społecznopolitycznych z szczegółowymi formami organizowania kobiet w różne organizacje religijno-kościelne $\mathrm{z}$ mocnym akcentem na formację patriotyczną kobiet polskich. Tematem artykułu jest też zaangażowanie kapucynów w pracę duszpasterską wśród kobiet i aktywność polityczną w połowie XIX wieku.
\end{abstract}

Slowa kluczowe: o. Beniamin Szymański, Klamentyna z Tańskich Hoffmanowa, Natalia Kicka, tercjarstwo franciszkańskie, „Przytulisko”, Związek Dobroczynności Patriotycznej, Żywy Różaniec.

\section{CONDITIONS OF THE SPIRITUALITY OF RELIGIOUS CONGREGATIONS OF HIDDEN LIFE IN THE KINGDOM OF POLAND IN THE $19^{\text {th }}$ CENTURY}

\begin{abstract}
The subject of the analysis is the spirituality of hidden religious life and its conditions. The truth about hidden God fascinated Honorat Koźmiński, a Capuchin who lived at the turn of the $19^{\text {th }}$ and $20^{\text {th }}$ centuries. He initiated more than 20 male and female religious congregations whose members did not wear uniform clothing and experienced their consecration in hiding from the world. Not wearing the habit, according to the plan of the Founder, was not determined solely by the socio-political situation. The article shows hiding as a special lifestyle characterized by humility, quietness, diligence and Franciscan minoritas. The article reflects on the commitment of the Capuchins and their formation work among men and women in socio-political and ecclesial conditions of the second half of the $19^{\text {th }}$ century.
\end{abstract}

Keywords: Spirituality, Franciscanism, Capuchins, Fr. Honorat Koźmiński, Franciscan Third Order, hidden monastic life, Living Rosary. 
